\title{
Asuhan Keperawatan Jiwa Pada Ny. F Dengan Masalah Halusinasi Pendengaran Di Ruangan Cempaka: Studi Kasus
}

\section{Sani Vandea Merisa Saragih}

\author{
Sanivandeasaragih31@gmail.com
}

\section{BAB 1 \\ PENDAHULUAN}

\subsection{Latar Belakang}

Gangguan jiwa merupakan masalah kesehatan yang serius karena meningkatnya jumlah penyakit, termasuk penyakit kronis dengan proses penyembuhan yang lama. Gangguan jiwa dibagi menjadi dua kategori, gangguan jiwa ringan dan gangguan jiwa berat. Gangguan mental yang berbahaya dan tidak terkendali adalah skizofrenia (Hartanto,2021). Skizofrenia adalah sekelompok reaksi psikotik yang mempengaruhi berbagai area fungsi individu, termasuk berpikir, berkomunikasi, merasakan, dan mengekspresikan emosi, serta gangguan otak yang ditandai dengan pikiran yang tidak teratur, delusi, halusinasi, dan perilaku aneh.(Pardede \& Ramadia, 2021). Skizofrenia adalah penyakit yang mempengaruhi berbagai area fungsi individu, termasuk: berpikir, berkomunikasi, menerima, menafsirkan realitas, merasakan, dan menunjukkan emosi (Pardede,2020). Menurut WHO (2021) prevelensi skizofrenia telah meningkat dari $40 \%$ menjadi 26 juta jiwa. Sedangkan di Indonesia prevelensi skizofrenia meningkat menjadi 20\% penduduk. Prevelensi Sumatera Utara meningkat menjadi 7\% penduduk (Riskesdes, 2018).

Departemen Kesehatan Republik Indonesia, Riset Kesehatan Dasar (Riskedas) tahun 2018, menyatakan bahwa jumlah gangguan jiwa berat psikosis/ skizofrenia di indonesia dimana provinsi - provinsi yang memiliki gangguan jiwa terbesar yaitu urutan pertama di Yogyakarta (0,27\%), urutan kedua Aceh $(0,27 \%)$, urutan ketiga Sulawesi Selatan $(0,26 \%)$, Bali menempati urutan ke empat (0,24\%), dan Sumatera Utara menempati posisi ke lima (0,23\%). Berarti bahwa provinsi Sumatera Utara menempati posisi ke lima (Riskesdas, 2018). Berdasarkan peningkatan pasien skizofrenia, perubahan respon persepsi 
merupakan gejala pertama yang muncul pada Skizofrenia. Sekitar 70\% Pasien Skizofrenia mengalami halusinasi (Kheliad, 2019).

Halusinasi merupakan suatu persepsi panca indera tanpa adanya stimulus eksternal. Dampak yang ditimbulkan dari adaya halusinasi adalah kehilangan kontrol diri, yang mana dalam situasi ini dapat membunuh diri ,membunuh orang lain, bahkan merusak lingkungan. Dalam memperkecil dampak yang ditimbulkan halusinasi dibutuhkan penangan yang tepat. Dengan banyaknya kejadian halusinasi, semakin jelas bahwa peran perawat untuk membantu pasien agar dapat mengontrol halusinasi (Shalahuddin, 2021). Menurut Yosep (2015), penyebab halusinasi ada beberapa faktor, seperti faktor perkembangan, faktor sosiokultural, faktor biokimia, faktor psikologis, faktor genetik dan pola asuh. Karena rendahnya kontrol dan kehangatan keluarga menyebabkan klien tidak mampu mandiri sejak kecil, mudah frustasi, hilang percaya diri dan lebih rentan terhadap stress, selain itu seseorang yang merasa tidak diterima di lingungannya akan merasa diasingkan, kesepian, tidak percaya diri dan malas untuk mencari pekerjaan atau karena faktor ekonomi, dan pernikahan.

Akibat dari halusinasi yang tidak ditangani juga dapat muncul hal-hal yang tidak diinginkan seperti halusinasi yang menyuruh pasien untuk melakukan sesuatu, seperti membunuh dirinya sendiri, melukai orang lain, atau bergabung dengan seseorang di kehidupan sesudah mati. Ketika berhubungan dengan orang lain, reaksi emosional mereka cenderung tidak stabil, intens dan di anggap tidak dapat di perkirakan. Melibatkan hubugan intim dapat memicu respon emosional yang ekstrim, misal ansietas, panik, takut, atau teror (Videbeck, 2016).

Berdasarkan survey awal dilakukan di ruangan cempaka terdapat 22 pasien dan yang menjadi kasus kelolaan adalah Ny. F berusia 44 Tahun mengalami halusinasi pendengaran. dan saat dikaji awalnya pasien gangguan jiwa karena banyak tekanan dari keluarga, adapun tanda-tanda yang dialami oleh klienn sering mondar-mandir dan bicara-bicara sendiri dan selalu berkata diusir-usir terus oleh saudaranya dan pasien belum bisa mengontrol halusinasinya. 


\subsection{Tujuan Penulisan}

\subsubsection{Tujuan Umum}

Memberikan asuhan keperawatan jiwa Kepada Pada Ny F dengan masalah gangguan persepsi sensori halusinasi pendengaran dan penglihatan Ruang Cempaka Rumah Sakit Jiwa Prof. Dr. Muhammad Ildrem Medan

\subsubsection{Tujuan Khusus}

1. Mahasiswa mampu mengetahui defenisi penyebab, tanda dan gejala, rentang respon dan penatalaksaanaan pada pasien waham kebesaran

2. Mahasiwa mampu melaksanakan pengkajian analisa data pada Ny. F dengan Halusinasi Pendengaran di Rumah Sakit Jiwa Prof Ildem Medan

3. Mahasiwa mampu menegakan diagnose keperawatan pada Ny. F dengan Halusinasi Pendengaran di Rumah Sakit Jiwa Prof Ildrem

4. Mahasiwa mampu menegakan Intervensi keperawatan pada Ny F Halusinasi Pendengaran di Rumah Sakit Jiwa Prof Ildrem

5. Mahasiwa mampu menegakan Intervensi keperawatan pada Ny. F dengan Halusinasi Pendengaran di Rumah Sakit Jiwa Prof Ildrem

6. Mahasiwa mampu menegakan Implementasi keperawatan pada Ny. F Halusinasi Pendengaran di Rumah Sakit Jiwa Prof Ildrem

7. Mahasiwa mampu menegakan mengevaluasi keperawatan pada N F halusinasi pendengaran di Rumah Sakit Jiwa Prof Ildr 


\subsection{Konsep Halusinasi}

\subsubsection{Defenisi Halusinasi}

Halusinasi merupakan salah satu gejala yang sering ditemukan pada klien dengan gangguan jiwa.halusinasi identik dengan skizofrenia. Seluruh klien skizofrenia diantaranya mengalami halusinasi. Halusinasi merupakan gangguan persepsi dimana klien mempersepsikan sesuatu yang banyak terjadi. Suatu penerapan panca indra tanpa ada rangsangan dari luar. Suatu penghayatan yang dialami seperti suatu persepsi melalui panca indra tanpa stimulus eksternal ; persepsi palsu. Berbeda dengan ilusi dimana klien mengalami persepsi pada halusinasi yang terjadi tanpa adanya stimulus yang terjadi. Stimulus internal dipersepsikan sebagai suatu yang nyata ada oleh klien, (Muhith, 2015). Halusinasi adalah suatu keadaan dimana klien mengalami perubahan sensori persepsi yang disebabkan stimulus yang sebenarnya itu tidak ada (Herawati, 2020).

Halusinasi pendengaran menurut Nanda Nic-Noc (2015) yaitu seperti mendengar suara yang membicarakan, mengejek, menertawakan, mengancam, memerintahkan untuk melakukan sesuatu. Dari beberapa pengertian yang dikemukakan oleh para ahli mengenai halusinasi di aztas, maka penulis dapat mengambil kesimpulan bahwa halusinasi adalah persepsi klien yang salah melalui panca indra terhadap lingkungan tanpa ada stimulus atau rangsangan yang nyata. sedangkan halusinasi pendengaran adalah kondisi di mana pasien mendengar suara, terutama suara-suara orang yang sedang membicarakan apa yang sedang dipikirkannya dan memerintahkan untuk melakukan sesuatu (Keliat, 2015). Berdasarkan beberapa defenisi diatas halusinasi merupakan gangguan persepsi panca Indera ,adanya stimulus eksternal yang merasakan sensasi palsu namun tidak dapat dirasakan oleh orang lain.

\subsection{Tanda dan Gejala}

Tanda dan gejala merupakan halusinasi dinilai dari hasil observasi terhadap pasien serta ungkapan pasien. Tanda dan gejala pasien halusinasi adalah sebagai berikut (Oktaviani, 2020)

\subsubsection{Data Objektif}

- Bicara atau tertawa sendiri

- Marah-marah tanpa sebab

- Memalingkan muka ke arah telinga seperti mendengar sesuatu

- Menutup telinga

- Menunjuk-nunjuk ke arah tertentu 
- Ketakutan pada sesuatu yang tidak jelas

- Mencium sesuatu seperti sedang membaui bau-bauan tertentu

- Menutup hidung

- Sering meludah

- Muntah

- Respon yang tidak sesuai

- Menarik diri

- Respon yang tidak sesuai

- Suka marah dengan tiba- tiba dan menyerang orang lain tanpa sebab.

- Sering melamun

- Menggaruk-garuk permukaan kulit

\subsubsection{Data subjektif}

1) Mendengar suara-suara atau kegaduhan

2) Mendengar suara yang mengajak bercakap-cakap

3) Mendengar suara menyuruh melakukan sesuatu yang berbahaya

4) Melihat bayangan, sinar, bentuk geometris, bentuk kartun, melihat hantu atau monster

5) Mencium bau-bauan seperti bau darah, urin, feses, kadang-kadang bau itu menyenangkan

6) Merasakan rasa seperti darah, urin atau feses

7) Merasa takut atau senang dengan halusinanya

8) Mengatakan sering mengikuti isi perintah halusinasi

\subsection{Proses Terjadinya Halusinasi}

\subsubsection{Faktor Predisposisi}

Faktor predisposisi sebagai faktor risiko yang menjadi sumber terjadinya stres yang mempengaruhi tipe dan sumber dari individu untuk menghadapi stres baik yang biologis, psikososial dan sosial kultural. Penjelasan secara rinci tentang ketiga stressor predisposisi tersebut sebagai berikut (Keliat, 2015) :

1. Faktor Perkembangan

Hambatan perkembangan akan mengganggu hubungan interpersonal yang dapat meningkatkan stress dan ansietas yang dapat berakhir dengan ganggguan persepsi. Pasien mungkin menekan perasaannya sehingga 
pematangan fungsi intelektual dan emosi tidak efektif.

2. Faktor Sosial Budaya

Berbagai faktor di masyarakat yang membuat seseorang merasa disingkirkan atau kesepian, selanjutnya tidak dapat diatasi sehingga timbul gangguan seperti delusi dan halusinasi.

3. Faktor Psikologis

Hubungan interpersonal seseorang yang tidak harmonis, serta peran ganda atau peran yang bertentangan dapat menimbulkan ansietas berat berakhir dengan pegingkaran terhadap kenyataan, sehingga terjadi halusinasi.

4. Faktor Biologis

Struktur otak yang abnormal ditemukan pada pasien gangguan orientasi realitas, serta dapat ditemukan atropik otak, perubahan besar, serta bentuk sel kortikal dan limbic.

5. Faktor Genetik

Gangguan orientasi realitas termasuk halusinasi umumnya ditemukan pada pasien skizofrenia. Skizofrenia ditemukan cukup tinggi pada keluarga yang salah satu anggota keluarganya mengalami skizofrenia, serta akan lebih tinggi jika kedua orang tua skizofrenia.

\subsubsection{Faktor Presipitasi}

Secara umum klien dengan gangguan halusinasi timbul gangguan setelah adanya hubungan yang bermusuhan, tekanan, isolasi, perasaan tidak berguna, putus asa dan tidak berdaya.Stressor presipitasi bisa berupa stimulus internal maupun eksternal yang mengancam individu. Komponen stressor presipitasi terdiri atas sifat, asal, waktu dan jumlah stressor (Stuart, 2015). Sifat stresor, terjadinya halusinasi berdasarkan sifat terdiri dari (Jelika, 2015) : 
Stress dan kecemasan akan meningkat bila terjadi penurunan stabilitas keluarga, perpisahan dengan orang yang penting, atau diasingkan dari kelompok dapat menimbulkan halusinasi.

2. Faktor Biokimia

Penelitian tentang dopamin, norepinetrin, indolamin, serta zat halusigenik diduga berkaitan dengan gangguan orientasi realitas termasuk halusinasi.

3. Faktor Psikologis

Intensitas kecemasan yang ekstream dan memanjang disertai terbatasnya kemampuan mengatasi masalah memungkinkan berkembangnya gangguan orientasi realistis. Pasien mengembangkan koping untuk menghindari kenyataan yang tidak menyenangkan.

4. Faktor Perilaku

Perilaku yang perlu dikaji pada pasien dengan gangguan orientasi realitas berkaitan dengan perubahan proses pikir, afektif persepsi, motorik, dan social.

Saat pertama kali terkena masalah, maka penanganannya juga memerlukan suatu upaya yang lebih intensif dengan tujuan untuk pencegahan primer. Frekuensi dan jumlah stresor juga mempengaruhi individu, bila frekuensi dan jumlah stresor lebih sedikit juga akan memerlukan penanganan yang berbeda dibandingkan dengan yang mempunyai frekuensi dan jumlah stresor lebih banyak. Berbagai penyebab/stressor di atas, yang meliputi stressor predisposisi dan stressor presipitasi yang dialami oleh klien halusinasi akan memunculkan beberapa respon. Respon tersebut merupakan pikiran, sikap, tanggapan, perasaan dan perilaku yang ditunjukkan pada klien halusinasi terhadap kejadian yang dialami (Hidayat, 2015). 


\begin{tabular}{|c|c|}
\hline Jenis Halusinasi & Karakteristik \\
\hline Pendengaran & $\begin{array}{l}\text { Mendengar suara-suara atau kebisingan, paling } \\
\text { sering suara orang,suara berbentuk kebisingan yang } \\
\text { kurang keras sampai kata- katayang jelas berbicara } \\
\text { tentang klien, bahkan sampai percakapan } \\
\text { lengkapantara dua orang atau lebih. Pikiran yang } \\
\text { didengar klien dimana klien disuruh untuk } \\
\text { melakukan sesuatu yang kadang-kadang } \\
\text { membahayakan. }\end{array}$ \\
\hline Penglihatan & $\begin{array}{l}\text { Stimulus visual dalam bentuk kelihatan cahaya, } \\
\text { gambaran geometris,gambaran kartun, bayangan } \\
\text { yang rumit dan kompleks. Bayangan bisa } \\
\text { menyenangkan atau menakutkan seperti melihat } \\
\text { monster. }\end{array}$ \\
\hline Penghidungan & $\begin{array}{l}\text { Menghirup bau-bauan tertentu seperti bau darah,bau } \\
\text { urin,atau bau feses, umumnya bau- bauan yang tidak } \\
\text { menyenangkan.Halusinasi penghidu sering akibat } \\
\text { dari stroke,tumor,kejang atau dimensia. }\end{array}$ \\
\hline Pengecapan & $\begin{array}{l}\text { Merasa mengecap rasa sesuatu } \\
\text { Seperti darah,urin atau feses. }\end{array}$ \\
\hline Perabaan & $\begin{array}{l}\text { Mengalami nyeri atauketidaknyamanan tanpa } \\
\text { stimulusyang jelas.Rasa tersetrum listrik yang datang } \\
\text { dari tanah, benda mati atau oranglain. }\end{array}$ \\
\hline Cenesthetics & $\begin{array}{l}\text { Merasakan fungsi tubuh seperti aliran darah divena } \\
\text { atau arteri, pencernaan makanan atau pembentukan } \\
\text { urin. }\end{array}$ \\
\hline Kinesthetics & Merasakan pergerakan saat berdiri tanpa bergerak. \\
\hline
\end{tabular}

\subsection{Rentang Respon Halusinasi}




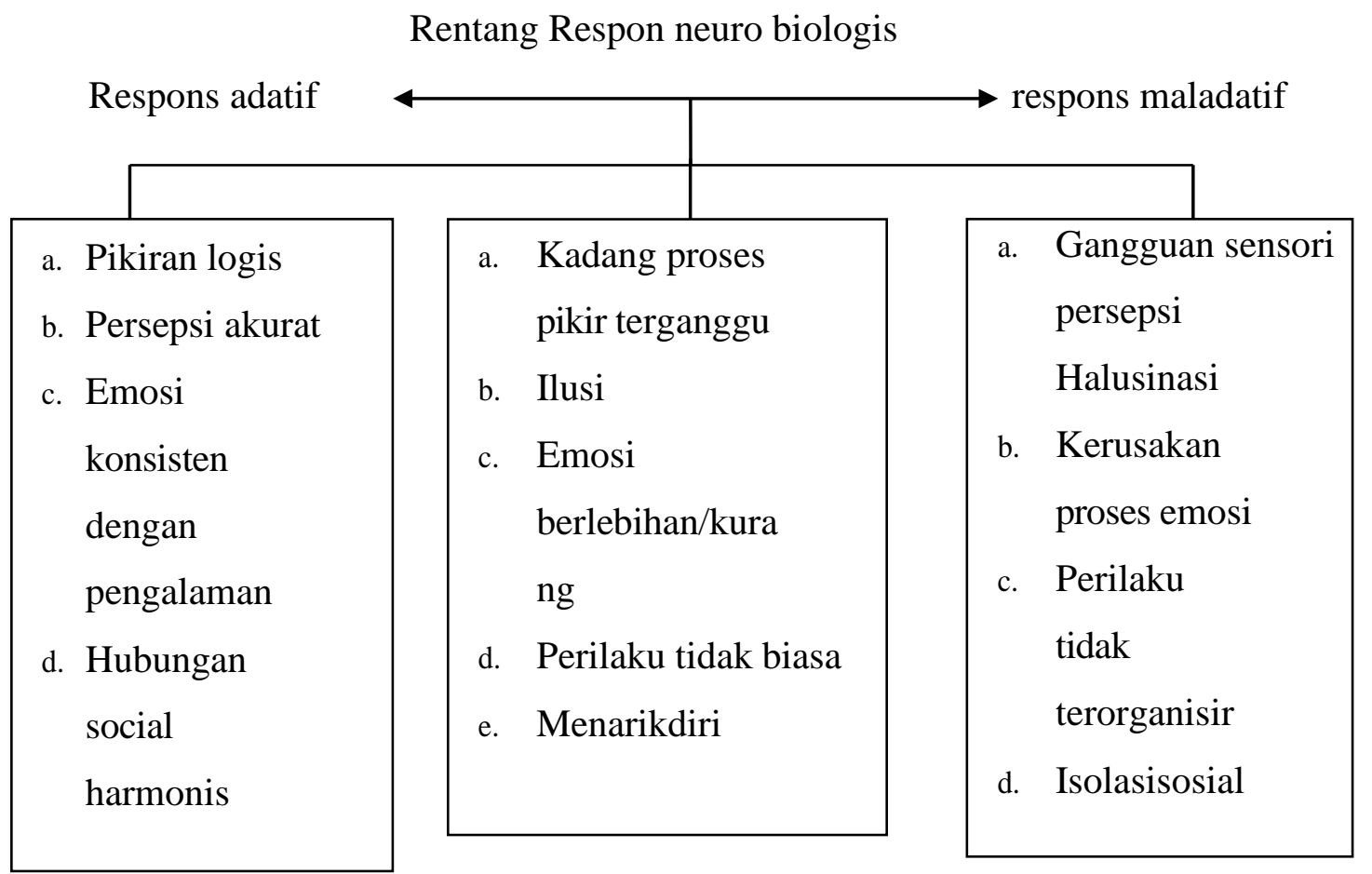

Gambar 2.1 rentang respon Halusinasi (Muhith, 2015)

Halusinasi dalam salah satu respon maladaptif individu yang berada dalam rentang respon neurobiologis Ini merupakan respon persepsi paling maladaptif.Jika klien sehat maka persepsi nya akurat, mampu mengidentifikasi dan menginterfrestasikans timulus berdasarkan informasi yang diterima melalui pancaindra pendengaran, penglihatan, penghidu, pengecapan, dan perabaan), klien dengan halusinasi mempersepsikan suatu stimulus panca indra walaupun sebenarnya stimulus tersebut tidak ada. Respon individu (yang karena suatu hal mengalami kelainan persepsi) yaitu salah mempersepsikan stimulus yang diterimanya yang disebut dengan ilusi. Klien mengalami ilusi jika interpretasi yang dilakukan terhadap stimulus panca indera tidak akurat sesuai dengan stimulus yang diterima. Respon tersebut digambarkan seperti gambar diatas. (Erliyani, 2019).

\subsection{Faktor Yang Mempengaruhi Terjadinya Halusinasi}

Halusinasi suatu salah satu gejala dalam menentukan diagnosis klien yang mengalami psikotik. Khususnya skizofrenia. Halusinasi dipengaruhi oleh factor, dibawah ini antara lain (Oktaviani, 2020):

\subsubsection{Faktor Predisposisi}

Adalah faktor resiko yang mempengaruhi jenis dan jumlah sumber yang dapat di bangkitkan oleh individu untuk mengatasi stress. Diperoleh baik dari klien 
maupun

keluarganya, mengenai faktor perkembangan sosial kultural, biokimia, psikologis, dan genetik. Beberapa factor predisposisi yang berkontribusi pada munculnya respon neurobiology seperti pada halusinasi antara lain (Erliyani, 2019).:

1) Faktor Genetik

Telah diketahui bahwa secara genetik skizofrenia diturunkan melalui kromosom- kromosom tertentu. Namundemikian,kromosom yang keberapa yang menjadi faktor penentu gangguanini sampai sekarang masih dalam tahap penelitian. Anak kembar identik memiliki kemungkinan mengalami skizofrenia sebesar 50\% jika salah satunya mengalami skizofrenia, sementara dizygote peluangnya sebesar 15\%. Seorang anak yang salah satunya orangtuanya mengalami skizofrenia berpeluang15\% mengalami skizofrenia, sementara bila kedua orang tuanya skizofrenia maka peluangnya menjadi $35 \%$ (Nyumirah, 2015).

2) Faktor Perkembangan

Jika tugas perkembangan mengalami hambatan dan hubungan interpersonal terganggu, maka individu akan mengalami stress dan kecemasan.

3) Faktor neurobiology

Ditemukan bahwa kortex pre frontal dan kortex limbic pada klien dengan skizofrenia tidak pernah berkembang penuh.Ditemukan juga pada klens kizofrenia terjadi penurunan volume dan fungsi otak yang abnormal. Neurotransmitter juga tidak ditemukan tidak normal,khususnya dopamine, serotonin dan glutamat.

4) Faktor biokimia

Mempunyai pengaruh terhadap terjadinya gangguan jiwa. Dengan adanya stress yang berlebihan yang dialami seseorang, maka tubuh akan menghasilkan suatu zat yang dapat bersifat halusinogenik neurokimia seperti Buffofenon dan Dimetytranferase (DMP).

5) Faktor Sosiol cultural

Berbagi factor yang terjadi dimasyarakat dapat menyebabkan seorang merasa disingkirkan oleh kesepian terhadap lingkungan tempat klien dibesarkan.

6) Psikologis

Beberapa kondisi psikologis terjadi menjadi faktor predisposisi skizofrenia, anatara lain anak yang diperlakukan oleh ibuyang pencemas, terlalu 
melindungi, dingin dan

tidak berperasaan,sementara ayah yang mengambil jarak dengan anaknya. Sementaraitu hubungan interpersonal yang tidak harmonis serta adanya perangan dayang bertentangan dan sering diterima oleh anak akan mengakibatkan stress dan kecemasan yang tinggi dan berakhir dengan gangguan orientasi realitas (Erviana, 2018).

\subsubsection{Faktor Presipitasi}

Adanya rangsang lingkungan yang sering yaitu seperti partisipasi klien dalam kelompok, terlalu lama diajak komunikasi dan suasana sepi/isolasi sering sebagai pencetus terjadinya halusinasi karena hal tersebut dapat meningkatkan stress dan kecemasan yang merangsang tubuh mengeluarkan zat halusinogenik. Disamping itu jugaoleh karena proses penghambatan dalam proses transduksi dari impulsyang menyebabkan terjadinya penyimpangan dalam proses interpretasidan interkoneksi sehingga dengan demikian faktor-faktor pencetus respon neurobiologis dapat dijabarkan sebagai berikut (Yusuf, 2015):

1) Berlebihnya proses informasi pada sistem syaraf yang menerima dan memproses informasi di thalamus dan frontal otak.

2) Mekanisme penghantaran listrik disyaraf terganggu (mekanisme gatting abnormal).

3) Gejala-gejala pemicu seperti kondisi kesehatan, lingkungan, sikap, dan perilaku

\subsection{Validasi Informasi Tentang Halusinasi}

Halusinasi benar-benar nyata dirasakan oleh klien yang mengalaminya, seperti mimpi saat tidur. Klien mungkin tidak panya cara untuk menentukan persepsi tersebut secara nyata.Sama halnya seperti seseorang yang mendengarkan siaran ramalan cuaca dan tidak lagi meragukan orang yang berbicara tentang cuaca tersebut. Ketidakmampuan untuk mempersepsikan stimulus secara riil dapat menyulitkan kehidupan klien. Karenanya halusinasi menjadi prioritas untuk segera diatasi. Sangat penting untuk memberi kesempatan klien untuk menjelaskan tentang halusinasi yang dialaminya secara leluasa.Perawat membutuhkan kemampuan untuk berbicara tentang halusinasi karena dengan perbincangan halusinasi dapat menjadi indikator sejauh mana gejala psikotik klien diatasi. Untuk memfasilitasinya. Klien

perlu dibuat nyaman untuk menceritakan perihal halusinasinya. Klien yang mengalami halusina sisering kecewa karena mendapatkan respon negative ketika mereka 
menceritakan halusinasinya kepada orang lain. Karenanya banyak klien kemudian enggan untuk menceritakan pengalaman - pengalaman aneh halusinasinya (Wahyuni, 2015).

Pengalaman halusinasi menjadi masalah untuk dibicarakan dengan orang lain. Kemampuan untuk bercakap-cakap tentang halusinasi yang dialami oleh klien sangat penting untuk memastikan dan memvalidas ipengalaman halusina sitersebut. Perawat harus memiliki ketulusan dan perhatian yang penuh untuk dapat memfasilitasi percakapan tentang halusinasi. Perilaku klien yang mengalami halusinasi sangat tergantung pada jenis halusinasinya, apakah halusinasinya merupakan halusinasi pendengaran, penglihatan, penghidu, pengecapan, perabaan, kinestetik, cenesthetic. Apakah perawat mengidentifikasi adanya tanda- tanda dan perilaku halusinasi, maka pengkajian selanjutnya harus dilakukan tidak hanya sekedar mengetahui jenis halusinasinya saja. Validasi informasi tentang halusinasi yang dilakukan meliputi (Yusuf, 2015) :

1. Isi Halusinasi,yang dialami oleh klien. Ini dapat dikaji dengan menanyakan suara siap yang didengar dan apa yang dikatakan berkata jika halusinasi yang dialami adalah halusinasi dengar. Bentuk bayangan bagaimana yang dilihat klien bila jenis halusinasinya adalah halusina sipenglihatan, bau apa yang dicium jika halusinasinya adalah halusinasi penghidu, rasa apayang dikecap untuk halusinasi pengecapan, atau merasakan apadipermukaan tubuh bila mengalami halusinasi perabaan.

2. Waktu dan Frekuensi Halusinasi, ini dapat dikaji dengan menanyakan kepada klien kapan pengalaman halusinasi muncul, berapahari sekali, seminggu atau sebulan pengalaman halusinasi itu muncul.Informasi ini penting untuk mengidentifikasi pencetus halusinasi dan menentukan bilamanak lienperludi perhatikan saat mengalami halusinasi.

3. Situasi pencetus Halusinasi, perawat perlu mengidentifikasi situasi yang dialami klien sebelum mengalami halusinasi. Ini dapat dikaji dengan menanyakan kepada klien peristiwa atau kejadian yang dialami sebelum halusina siini muncul .Selain itu perawat juga bisa mengobserva siapa yang dialami klien menjelang muncul halusinasi untuk memvalidasi pernyataan klien.

4. Respon klien, untuk menentukan sejauh mana halusina sitelah mempengaruhi klien, bisa dikaji dengan menanyakan apa yang dilakukan klien saat mengalami pengalaman halusinasi. Apakah klien masih bisa mengontrol stimulasi halusinasi atau sudah tidak berdaya lagi terhadap halusinasi (Stuart \& Laraia, 2017). 


\subsection{Penatalaksanaan Halusinas}

\subsubsection{Penatalaksanaan medis}

Penatalaksanaan klien skizofrenia yang mengalami halusinasi adalah dengan pemberian obat-obatan dan tindakan adalah ( Kelit, 2015) :

1. Psikofarmologi, obat yang lazim digunakan pada gejala halusinasi pendengaran yang merupakan gejala psikosis pada klien skizofrenia adalah obat anti psikosis. adapun kelompok yang umum digunakan adalah fenotiazine asetofenazin (tindal). klorpromazin (thorazine), Flufenazin (prolixine, permitil), mesoridazin (serentil), perfenazin (trilafon), prokloperazin (compazin), Promazin (sparine), tioridazin (mellari),trifluoperazin (stelazine), trifluopromazin (vesprin), 60-120 mg, tioksanten klorproiksen (taractan), tioksen (navane) 75-600 mg. buttirofenom haloperidol (haldol) 1-100 mg, dibenzokasazepin loksapin (loxitan) 20-150 mg, dihidroindolon molindone (moban) 15-225 mg.

2. Terapi kejang listrik / Electro compulsive therapt (ECT)

ECT adalah pengobatan untuk menimbulkan kejang grandmall secara artificial dengan melawan aliran listrik melalui electrode yang dipasang pada satu atau dua temples, terapi kejang listrik diberikan pada skizoprenia yang tidak mempan dengan terapi neuroleptika oral atau injeksi, dosis terapi kejang listrik 4-5 joule /detik (Trisna, 2021)

\subsubsection{Penatalaksanaan keperawatan}

1. Terapi aktifitas kelompok (TAK)

Penatalaksanaan pada sesi 2 sampai 5 terapi aktifitas kelompok stimulasi persepsi dilakukan untuk stimulasi menghardik halusinasi, stimulasi persepsi mengonrol halusinasi dengan melakukan kegiatan, stimulasi persepsi mengontrol halusinasi dengan bercakap-cakap dan stimulasi persepsi mengontrol dengan patuh minum obat (Wijayanti,2008). .

2. Menganjarkan SP kepada pasien halusinasi (Ngapiyem,2019).

1) Stategi pelaksanaan 1 keluarga: mengenal masalah dalam merawat klien halusinasi klien halusinasi dan melatih mengontrol halusinasi dengan cara menghardik,

2) Stategi pelaksanaan 1 keluarga: Melatih keluarga merawat klien halusinasi dengan enam benar minum obat

3) Stategi pelaksanaan 1 keluarga: Melatih keluarga merawat klien halusinasi dengan bercakap-cakap dengan orang lain,

4) Stategi pelaksanaan 1 keluarga: Melatih keluarga memanfaatkan fasilitas 


\section{kesehatan dan follow up}

\subsection{Konsep Dasar Asuhan Keperawatan}

\subsubsection{Pengkajian}

Pengkajian merupakan pengumpulan data subjektif dan objektif secara, sistematis dengan tujuan membuat penentuantindakan keperawatan bagi individu,kekuarga dan komunitas (Damayanti \& Iskandar, 2016). Gangguan halusinasi merupakan salah satu yang dapat ditemukan pada pasien gangguan jiwa. Dan berisikan pedoman agar perawat dapat melakukan asuhan keperawatan jiwa (Keliat, 2015). Pada tahap ini ada beberapa yang perlu dieksplorasi baik pada klien yang berkenaan dengan kasus halusinasi yang meliputi :

1) Identitas klien

Meliputi nama klien, umur, jenis kelamin, status perkawinan, Agama, tanggal MRS, informan, tanggal pengkajian, nomor rumah klien, dan alamat klien.

2) Keluhan utama

Keluhan utama Biasanya berupa bicara sendiri, tertawa sendiri, senyum sendiri, menggerakkan bibir tanpa suara, menarik diri dari orang lain, tidak dapat membedakan yang nyata dan tidak nyata, ekspresi muka tegang mudah tersinggung, jengkel dan marah ketakutan biasa terdapat disorientasi waktu tempat dan orang, tidak dapat mengurus diri dan tidak melakukan kegiatan sehari-hari.

\section{1) Faktor predisposisi}

Faktor predisposisi adalah faktor resiko yang mempengaruhi jenis dan jumlah sumber yang dapat dibangkitkan oleh individu untuk mengatasi stres. Diperoleh baik dari klien maupun keluarganya, mengenai faktor perkembangan sosial kultural, biokimia psikologis dan genetik yaitu faktor resiko yang mempengaruhi jenis dan jumlah sumber yang dapat dibangkitkan oleh individu untuk mengatasi stress (Prabowo, 2014).

1. Faktor perkembangan; biasanya tugas perkembangan mengalami hambatan dan hubungan interpersonal terganggu maka individu akan mengalami stres dan kecemasan ( Susilawati, 2019).

2. Faktor sosiokultural ; berbagai faktor di masyarakat dapat menyebabkan seseorang merasa disingkirkan oleh kesepian terhadap lingkungan tempat klien dibesarkan.

3. Faktor biokimia ; adanya stres yang berlebihan dialami seseorang maka di 
dalam tubuh akan dihasilkan suatu zat yang dapat bersifat halusinogenik neuro kimia.

4. Faktor psikologis; hubungan interpersonal yang tidak harmonis, adanya peran ganda yang bertentangan dan tidak diterima oleh anak akan mengakibatkan stres dan kecemasan yang tinggi dan berakhir dengan gangguan orientasi realitas seperti halusinasi ( Erviana, 2018).

5. Faktor genetik; Apa yang berpengaruh dalam skizoprenia. Belum diketahui, tetapi Hasil studi menunjukkan bahwa faktor keluarga menunjukkan hubungan yang sangat berpengaruh pada penyakit ini.

2) Faktor presipitasi

Adanya rangsangan lingkungan yang sering yaitu seperti partisipasi klien dalam kelompok, terlalu lama Diajak komunikasi objek yang ada di lingkungan juga suasana sepi / isolasi adalah sering sebagai pencetus terjadinya halusinasi karena hal tersebut dapat meningkatkan stres dan kecemasan yang merangsang tubuh mengeluarkan zat halusinogenik (Yusuf, 2015).

3) Aspek fisik

Hasil pengukuran tanda vital (TD, nadi, suhu, pernapasan, TB, BB) dan keluhan fisik yang dialami oleh klien. Terjadi peningkatan denyut jantung pernapasan dan tekanan darah.

4) Aspek psikososial

Genogram yang menggambarkan tiga generasi.

5) Konsep diri (Zuraida, 2018).

1. Citra tubuh

Menolak melihat dan menyentuh bagian tubuh yang berubah/ tidak menerima perubahan tubuh yang terjadi / yang akan terjadi. Menolak penjelasan perubahan tubuh, persepsi negatif tentang tubuh. Preokupasi dengan bagian tubuh yang hilang, mengungkapkan keputusasaan, mengungkapkan ketakutan.

2. Identitas diri

Ketidakpastian memandang diri, sukar menetapkan keinginan dan tidak mampu mengambil keputusan.

3. Peran

Berubah / berhenti fungsi peran yang disebabkan penyakit, proses menua putus sekolah dan PHK.

4. Identitas diri 
Mengungkapkan keputusasaan karena penyakitnya dan mengungkapkan

keinginan yang terlalu tinggi

\section{Harga diri}

Perasaan malu terhadap diri sendiri, rasa bersalah terhadap diri sendiri, gangguan hubungan sosial, merendahkan martabat, mencederai diri dan kurang percaya diri.

6) Status mental

Pada pengkajian merupakan status mental pasien halusinasi ditemukan data berupa bicara sendiri, senyum sendiri, tertawa sendiri, menggerakkan bibir tanpa suara, pergerakan mata yang cepat, respon verbal yang lambat, menarik diri dari orang lain berusaha untuk menghindari orang lain, tidak dapat membedakan yang nyata dan tidak nyata, terjadi peningkatan denyut jantung pernapasan dan tekanan darah, perhatian dengan lingkungan yang kurang / hanya beberapa detik com berkonsentrasi dengan pengalaman sensori, sulit berhubungan dengan orang lain, ekspresi muka tegang, mudah tersinggung, jengkel dan marah tidak mampu mengikuti perintah dari perawat, tampak tremor dan berkeringat, perilaku panik, agitasi dan kataton curiga dan bermusuhan, bertindak merusak diri orang lain dan lingkungan, ketakutan, tidak dapat mengurus diri, biasa terdapat disorientasi waktu tempat dan orang ( Erviana, 2018).

7) Mekanisme koping

Dalam mendapat masalah, pasien takut / tidak mau menceritakan kepada orang lain (koping menarik diri). Mekanisme koping yang digunakan pasien sebagai usaha mengatasi kecemasan yang merupakan suatu kesepian nyata yang mengancam dirinya. Mekanisme koping yang sering digunakan pada halusinasi adalah (Erviana,2018).

1. Regresi : menjadi malas beraktivitas sehari-hari.

2. Proyeksi : menjelaskan perubahan suatu persepsi dengan berusaha untuk mengalihkan tanggung jawab kepada orang lain.

3. Menarik diri : sulit mempercayai orang lain dan asyik dengan stimulus internal.

8) Aspek medic

Terapi yang diterima klien bisa berupa terapi farmakologi psikomotor terapi okupasional, TAK dan rehabilitas.

\subsubsection{Diagnosa Keperawatan}


Ada beberapa diagnosa keperawatan yang sering ditemukan pada klien dengan halusinasi (Damaiyanti 2015) iyalah:

1) Gangguan sensori persepsi: halusinasi

2) Gangguan isolasi sosial: menarik diri

3) Gangguan Konsep Diri: Harga diri rendah

\subsubsection{Perencanaan Keperawatan}

Keperawatan Rencana tindakan pada keluarga (dalam Wijayati, 2019) adalah

1) Diskusikan masalah yang dihadap keluarga dalam merawat pasien

2) Berikan penjelasan meliputi: pengertian halusinasi, proses terjadinya halusinasi, jenis halusinasi yang dialami, tanda dan gejala halusinasi, proses terjadinya halusinasi.

3) Jelaskan dan latih cara merawat anggota keluarga yang mengalami halusinasi menghardik, minum obat, bercakap- cakap, melakukan aktivitas.

4) Diskusikan cara menciptakan lingkungan yang dapat mencegah terjadinya halusinasi.

5) Diskusikan tanda dan gejala kekambuhan

6) Diskusikan pemanfaatan fasilitas pelayanan kesehatan terdekat untuk follow up anggota keluarga dengan halusinasi.

Rencana tindakan keperawatan pada klien dengan diagnosa gangguan persepsi sensori halusinasi meliputi pemberian tindakan keperawatan berupa terapi (Zelika, 2015) yaitu

1. Bantu klien mengenal halusinasinya meliputi isi, waktu terjadi halusinasi, isi, frekuensi, perasaan saat terjadi halusinasi respon klien terhadap halusinasi mengontrol halusinasi dengan cara menghardik,

2. Meminum obat secara teratur.

3. Melatih bercakap-cakap dengan orang lain,

4. Menyusunkegiatan terjadwal dan dengan aktifitas

\subsubsection{Implementasi Keperawatan}

Disesuaikan dengan rencana tindakan keperawatan. Pada situasi nyata sering pelaksanaan jauh berbeda dengan rencana, hal ini terjadi karena perawat belum terbiasa menggunakan

rencana tertulis dalam melaksanakan tindakan keperawatan. Sebelum melaksanakan tindakan keperawatan yang sudah direncanakan, perawat perlu memvalidasi dengan singkat apakah rencana tindakan masih sesuai dan dibutuhkan klien sesuai dengan kondisinya (here and now). Perawat juga menilai diri sendiri, apakah kemampuan 
interpersonal, intelektual, tekhnikal sesuai dengan tindakan yang akan dilaksanakan, dinilai kembali apakah aman bagi klien. Setelah semuanya tidak ada hambatan maka tindakan keperawatan boleh dilaksanakan (Andri, 2019)

Adapun pelaksanaan tindakan keperawatan jiwa dilakukan berdasarkan. Strategi Pelaksanaan (SP) yang sesuai dengan masing-masing masalah utama. Pada masalah gangguan sensori persepsi: halusinasi pendengaran, terdapat 2 jenis SP, yaitu SP Klien dan SP Keluarga. SP klien terbagi menjadi SP 1 (membina hubungan saling percaya, mengidentifikasi halusinasi "jenis, isi, waktu, frekuensi, situasi, perasaan dan respon halusinasi", mengajarkan cara menghardik, memasukan cara menghardik ke dalam jadwal; SP 2 (mengevaluasi SP 1, mengajarkan cara minum obat secara teratur, memasukan ke dalam jadwal); SP 3 (mengevaluasi SP 1 dan SP 2, menganjurkan klien untuk mencari teman bicara); SP 4 (mengevaluasi SP 1, SP 2, dan SP 3, melakukan kegiatan terjadwal). SP keluarga terbagi menjadi SP 1 (membina hubungan saling percaya, mendiskusikan masalah yang dihadapi keluarga dalam merawat pasien, menjelaskan pengertian, tanda dan gejala helusinasi, jenis halusinasi yang dialami klien beserta proses terjadinya, menjelaskan cara merawat pasien halusinasi); SP 2 (melatih keluarga mempraktekan cara merawat pasien dengan halusinasi, melatih keluarga melakukan cara merawat langsung kepada pasien halusinasi); SP 3 (membantu keluarga membuat jadwal aktivitas di rumah termasuk minum obat (discharge planing), menjelaskan follow up pasien setelah pulang). Pada saat akan dilaksanakan tindakan keperawatan maka kontrak dengan klien dilaksanakan dengan menjelaskan apa yang akan dikerjakan dan peran serta klien yang diharapkan, dokumentasikan semua tindakan yang telah dilaksanakan serta respon klien (Irwan, 2021)

\subsubsection{Evaluasi Keperawatan}

Evaluasi adalah proses hasil atau sumatif dilakukan dengan membandingkan respon klien pada tujuan umum dan tujuan khusus yang telah ditentukan halusinasi pendengaran tidak terjadi perilaku kekerasan, klien dapat membina hubungan saling percaya, klien dapat mengenal halusinasinya, klien dapat mengontrol halusinasi dengar dari jangka waktu 4x24 jam didapatkan data subjektif keluarga menyatakan senang karena sudah diajarkan teknik mengontrol halusinasi, keluarga menyatakan pasien mampu melakukan beberapa teknik mengontrol halusinasi. Data objektif pasien tampak berbicara sendiri saat halusinasi itu datang, pasien dapat berbincang- 
bincang dengan orang lain, pasien mampu melakukan aktivitas terjadwal, dan minum obat secara teratur (Aji, 2019)

Evaluasi dapat dilakukan dengan menggunakan pendekatan SOAP sebagi pola pikir, dimana masing-masinghuruf tersebut akan diuraikan sebagai berikut:

S: Respon subjektif klien terhadap tindakan keperawatan yang telah dilaksanakan

O: Respon objektif klien terhadap tindakan keperawatan yang telah dilaksanakan

A: Analisa ulang terhadap data subjektif untuk menyimpulkan apakah masalah baru atau ada yang kontraindikasi dengan masalah yang ada

P: Perencanaan atau tidak lanjut berdasarkan hasil analisa pada respon klien 


\section{BAB 3}

\section{TINJAUAN KASUS}

\subsection{Identitas Klien}

Inisial

Alamat

Tanggal Pengkajian

Umur

Agama

Status

Informent
: Ny. F

: Rumah Sakit Jiwa Prof Muhamad Ildrem

: 26 Januari 2022

: 44 Tahun

: Muslim

: Belum menikah

: Status klien dan komunikasi dengan klien

\subsection{Keluhan Utama}

Sering mendengar suara-suara aneh ditelinga, sering mondar-mandir merasa gelisah dan bicara-bicara sendiri seolah berbicara dengan orang lain padahal tidak ada, dan dari data keluarga pasien bahwa pasien sudah pernah dibawa ke RSJ di Medan.

\subsection{Faktor Predisposisi}

Klien sudah pernah di rumah sakit jiwa dengan alasan yang sama namun pasien berhenti mengunakan obat, dan terulang lagi masuk kedua kali pada tanggal 10 januari 2022 dan sudah mendapatkan penanganan

Masalah Keperawatan: Gangguan persepsi Halusinasi Pendengaran

\subsection{Fisik}

Klien tidak memiliki keluhan fisik, saat dilakukan pemeriksaan tanda-tanda vital, didapatkan hasil TD : 120/90 mmHg ; $\mathrm{N}: 86 x / 1$; $\mathrm{S}: 36,5^{\circ} \mathrm{C}$; RR : 20x/i. Klien memiliki tinggi badan $160 \mathrm{~cm}$ dan berat badan $58 \mathrm{Kg}$.

\subsection{Genogram}

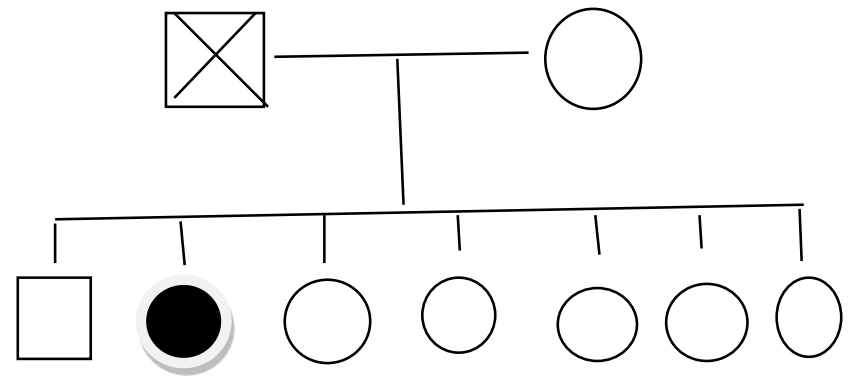

Keterangan:

: perempuan 


$$
\begin{aligned}
& \text { : laki-laki } \\
& \text { : klien Ny } \mathrm{F} \\
& \text { : cerai } \\
& \square: \text { garis keturunan } \\
& \bigotimes \text { : : meninggal perkawinan }
\end{aligned}
$$

Keterangan

Genogram :

Klien tinggal di Medan Johor,Sumatera Utara, Indonesia, Klien mempunyai ayah satu dan ibu satu, serta mempunyai Abang klien merupakan adalah anak ke dua dari enam bersaudara, klien dan keluarga dalam keadaan sehat fisik dan psikologis serta tidak mengalami gangguan jiwa ( sehat jiwa ).

\subsection{Konsep diri}

1. Gambaran Diri : Ny. F selalu berkata jika dirinya jelek, dan jika dikatakan Bahwa dia cantik di menganggap itu tidak boleh dan pantang.

2. Identitas : Ny. F mengenali dirinya dan berkata jika dirinya adalah perempuan dan mempunyai tugas sebagai perempuan

3. Peran :Ny. F sebagai perempuan tua yang belum menikah itu merasa dirinya tidak berguna

4. Ideal diri $\quad$ : Ny. F mengatakan kalo di segera sehat dan bisa bekerja kembali

5. Harga diri : Ny. F mengatakan bahwa dia malu dengan keadaan nya sekarang ini Masalah keperawatan: Gangguan konsep diri berhubungan dengan harga diri rendah

\subsection{Hubungan Sosial}

Klien mengganggap bahwa keluarganya iyalah orang yang sangat berarti dalam hidupnya, terutama pada ibu yang sudah berumur Klien tidak mengikuti kegiatan di kelompok/masyarakat. Klien mengatakan tidak ada hambatan dalam berkomunikasi

\subsection{Spiritual}

a. Nilai dan Keyakinan : Klien beragama Muslim

b. Kegiatan Ibadah : Selama di rawat di rumah sakit klien rajin untuk Shalat

\subsection{Status Mental}

1. Penampilan

Penjelasan : Klien berpenampilan kurang rapi namun 
mandi tiap pagi dan sore

2. Pembicaraan

Penjelasan : Klien saat di wawancarai berbicara lancar dan sesuai dengan topik pembicaraan

3. Aktivitas Motorik

Penjelasan : Klien mampu melaksanakan aktivitas sehari-hari

4. Suasana perasaan

Penjelasan : Klien mampu menuangkan perasaan sesuai kondisi yang di alami

5. Afek

Penjelasan : Klien merasa ada yang bicara dan ketawa sendiri dan bicara sendiri

Halusinasi pendengaran

6. Interaksi selama wawancara

Penjelasan : Selama diwawancarai klien bersikap kooperatif

7. Persepsi

Penjelasan : Klien mengatakan sering mendengar suara-suara yang menganggu dia Masalah keperawatan : Gangguan persepsi sensori : Halusinasi Pendengaran

8. Proses Pikir

Penjelasan : Klien mampu berbicara sesuai topik pembicara

9. Isi pikir

Penjelasan : Klien dapat mengontrol isi pikirnya, klien tidak mengalami gangguan isi pikir dan tidak ada waham. Klien tidak mengalami fobia, obsesi ataupun depersonalisasi.

10. Tingkat kesadaran

Penjelasan : Klien tidak mengalami gangguan orientasi, klien mengenali waktu, orang dan tempat.

11. Memori

Penjelasan : Klien mampu mengingat kejadian-kejadian yang dialaminya

12. Tingkat konsentrasi berhitung

Penjelasan: Klien mampu menjawab pertanyaan hitungan sederhana

13. Kemampuan penilaian

Penjelasan: Klien dapat membedakan hal baik dan buruk

14. Daya tilik diri : klien tidak mengingkari penyakit yang diderita klien mengetahui bahwa dia sedang sakit dan dirawat dirumah sakit jiwa

Masalah keperawatan : gangguan persepsi sensori : Halusinasi pendengaran

\subsection{Mekanisme Koping}


Klien mengalami mekanisme koping adaptif yaitu klien dapat berbicara baik dengan orang lain.

\section{3,11 Masalah Psikososial dan Lingkungan}

Klien mengatakan sulit berteman dengan orang lain karena klien selalu ingin menyendiri.

\subsection{Pengetahuan Kurang Tentang Gangguan Jiwa}

Klien mengetahui tentang gangguan jiwa dan klien paham tentang penyakitnya dan apa saja obat yang harus diminum dan kapan saja.

\subsubsection{Aspek Medik}

Diagnosa medis : Skizofrenia paranoid

Terapi medis yang diberikan :
a. Resperidone tablet $2 \mathrm{mg} 2 \times 1$
b. Clozapine $25 \mathrm{mg} 1 \mathrm{x} 1$
c. Haloperidon $2 \mathrm{mg} 2 \times 1$

\subsection{Analisa Data}

\begin{tabular}{|l|l|l|}
\hline No & Analisa Data & Masalah Keperawatan \\
\hline 1 & DS: & Halusinasi pendengaran \\
& & \\
\hline
\end{tabular}




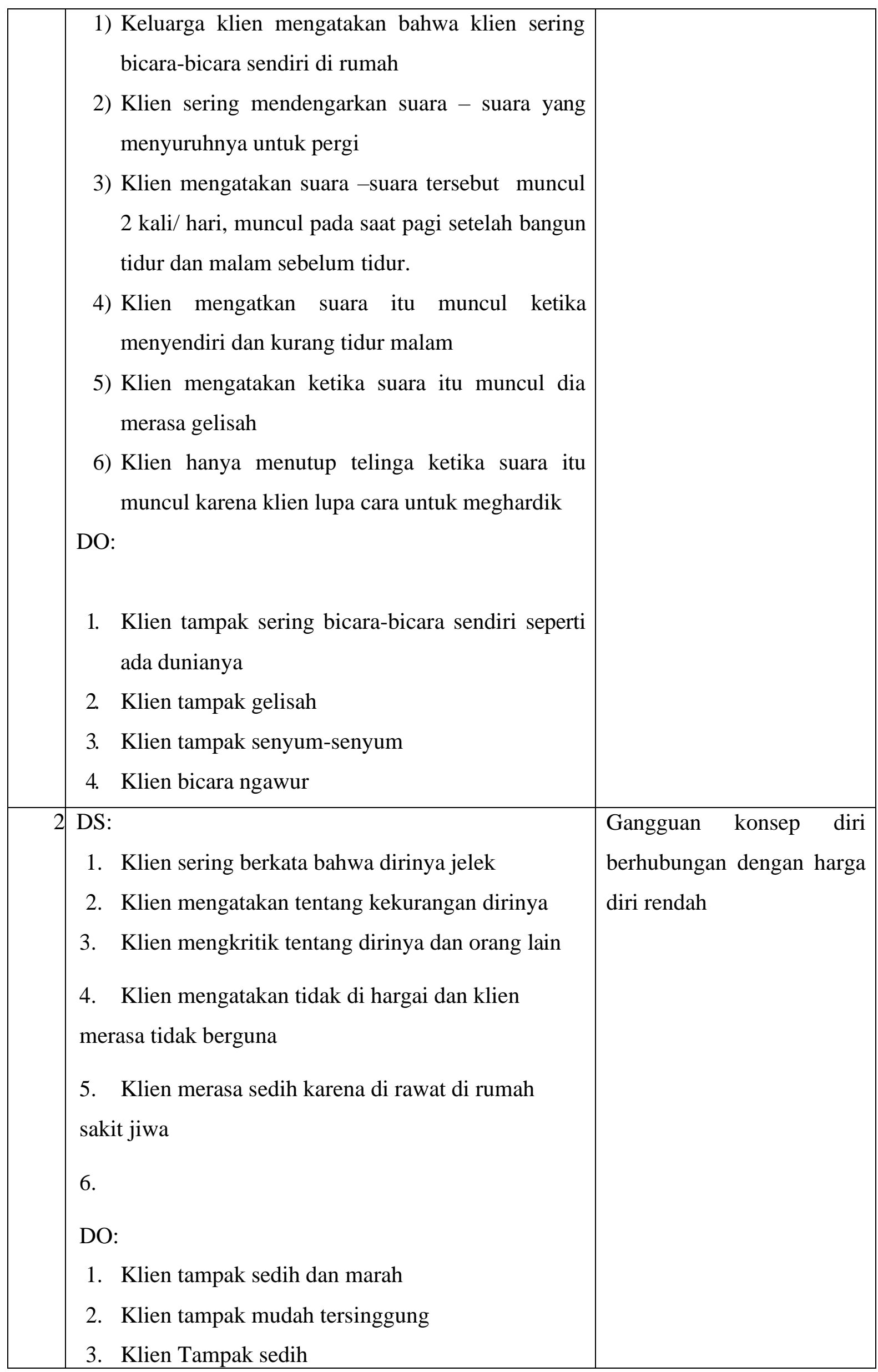




\begin{tabular}{|c|c|c|}
\hline & 4. Klien tampak tidak percaya diri saat di wawancara & \\
\hline 3 & $\begin{array}{l}\text { Ds : } \\
\begin{array}{l}\text { 1. Klien tidak mengikuti kegiatan di } \\
\text { keluarga,kelompok atau masyarakat } \\
\text { 2. Kien mempunyai hambatan dalam } \\
\text { berkomunikasi dengan orang lain } \\
\text { 3. Klien tampak menarik diri } \\
\text { 4. Klien tampak termenung sendiri } \\
\text { Do ; } \\
\text { 1. Klien tampak menghindari interaksi } \\
\text { dengan orang lain } \\
\text { 2. Klien tampak menarik diri dan susah } \\
\text { untuk bekomunikasi } \\
\text { 3. Klien tampak menyendiri dan sulit } \\
\text { bekomunikasi }\end{array}\end{array}$ & Isolasi Sosial \\
\hline
\end{tabular}

\subsection{Pohon Masalah}

\section{Gangguan Persepsi sensori: Halusinasi}

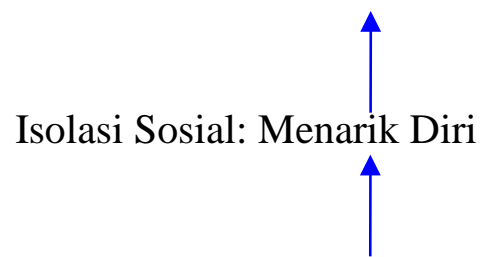

Gangguan konsep diri : Harga diri rendah Kronis

\subsection{Diagnosa keperawatan}

1. Gangguan Persepsi sensori : Halusinasi Pendengaran

2. Gangguan konsep diri: Harga diri rendah

3. Isolasi Sosial: Menarik diri 


\subsection{Intervensi keperawatan}

\begin{tabular}{|c|c|c|}
\hline No & Diagnosa Keperawatan & Intervensi \\
\hline 1. & Halusinasi pendengaran & $\begin{array}{l}\text { SP 1: } \\
\text { 1. Mengidentifikasi isi, frekuensi, } \\
\text { waktu terjadi, situasi pencetus, } \\
\text { perasaan daan respon halusinasi } \\
\text { 2. Mengontrol halusinasi dengan } \\
\text { menghardik } \\
\text { SP 2: } \\
\text { Mengontrol halusinasi dengan minum } \\
\text { obat secara teratur } \\
\text { SP 3: } \\
\text { Mengontrol halusinasi dengan } \\
\text { bercakap-cakap dengan orang lain } \\
\text { SP 4: } \\
\text { Mengontrol halusinasi dengan } \\
\text { melakukan kegiatan terjadwal }\end{array}$ \\
\hline 2. & $\begin{array}{l}\text { Gangguan Konsep diri b/d Harga diri } \\
\text { rendah }\end{array}$ & $\begin{array}{l}\text { SP 1: } \\
\text { 1. Pasien dapat mengindentifikasi } \\
\text { aspek positif } \\
\text { 2. Pasien dapat memiliki } \\
\text { kemampuan yang masih dapat } \\
\text { digunakan } \\
\text { SP 2: } \\
\text { Pasien dapat melakukan kegiatan } \\
\text { sesuai dengan jadwal yang dibuat } \\
\text { Pasien dapat berinteraksi dengan } \\
\text { orang lain tanpa terganggu }\end{array}$ \\
\hline 3 & Isolasi social & $\begin{array}{l}\text { SP 1 : } \\
\text { Menjelaskan keuntungan dan } \\
\text { kerugian mempunyai teman } \\
\text { SP 2 : } \\
\text { Melatih klien berkenalan dengan } 2 \\
\text { orang atau lebih } \\
\text { SP 3 : } \\
\text { Melatih klien bercakap-cakap sambil } \\
\text { melakukan kegiatan harian } \\
\text { SP. } 4 \text { : } \\
\text { Melatih klien berbicara social : } \\
\text { meminta sesuatu, berbelanja dan } \\
\text { sebagainya. }\end{array}$ \\
\hline
\end{tabular}




\subsection{Implementasi dan Evaluasi}

\begin{tabular}{|c|c|c|c|}
\hline Hari/Tgl & & Implementasi & Evaluasi \\
\hline $\begin{array}{l}\text { Rabu } \\
\text { 26/01/22 } \\
\text { Pukul } \\
\text { 15.00WIB }\end{array}$ & 3 & 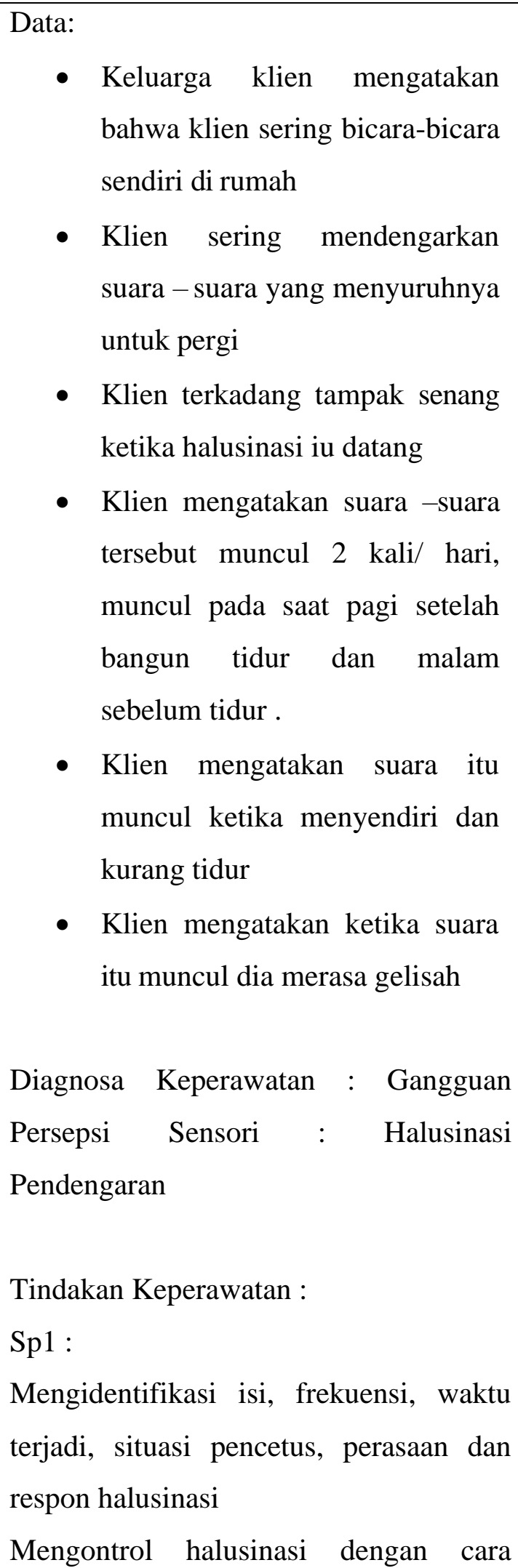 & 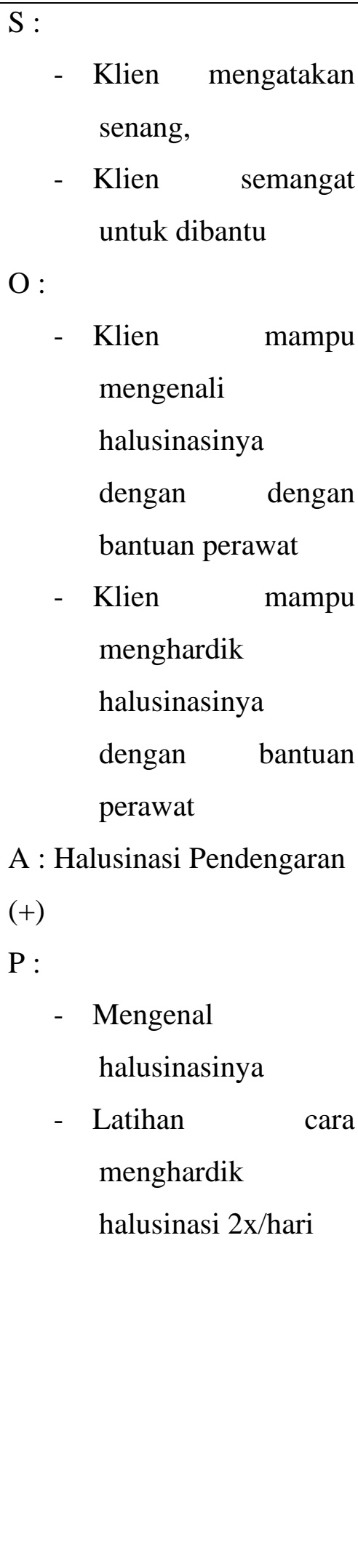 \\
\hline
\end{tabular}




\begin{tabular}{|c|c|c|}
\hline & $\begin{array}{ll} & \text { menghardik } \\
6 & \text { Mengidentifikasi jenis halusinasi } \\
7 & \text { Mengidentifikasi isi halusinasi } \\
8 & \text { Mengidentifikasi waktu halusinasi } \\
9 & \text { Mengindetifikasi situasi pencetus } \\
\text { halusinasi } \\
10 \text { Mengidentifikasi perasaan dan respon } \\
\text { halusinasi } \\
11 \text { Melatih cara mengontrol halusinasi } \\
\text { dengan menghardik } \\
\text { 12 } \text { Rencana Tindak Lanjut: } \\
\text { Sp2 : Mengontrol halusinasi dengan minum } \\
\text { obat secara teratur }\end{array}$ & \\
\hline $\begin{array}{l}\text { Kamis } \\
27 / 01 / 22 \\
\text { Jam } 14.00\end{array}$ & $\begin{array}{ll}\text { Data: } & \\
\text { - } & \text { Keluarga klien mengatakan } \\
& \text { bahwa klien sering bicara-bicara } \\
& \text { sendiri di rumah } \\
\text { - } & \text { Klien sering mendengarkan } \\
& \text { suara - suara yang menyuruhnya } \\
& \text { untuk pergi } \\
\text { - } & \text { Klien terkadang tampak senang } \\
& \text { ketika halusinasi iu datang } \\
\text { - } & \text { Klien mengatakan suara -suara } \\
& \text { tersebut muncul } 2 \text { kali/ hari, } \\
& \text { muncul pada saat pagi setelah } \\
& \text { bangun tidur dan malam } \\
& \text { sebelum tidur . } \\
\text { - } & \text { Klien mengatakan suara itu } \\
\text { muncul ketika menyendiri dan } \\
\text { kurang tidur } \\
\text { Klien mengatakan ketika suara } \\
\text { itu muncul dia merasa gelisah }\end{array}$ & $\begin{array}{ll}\text { S : } & \\
\text { O : } & \text { Klien tampak senang } \\
\text { - } & \text { Klien sudah mampu } \\
& \text { mengenali } \\
& \text { halusinasinya } \\
& \text { dengan mandiri } \\
\text { - } & \text { Klien mampu } \\
& \text { melakukan cara } \\
& \text { menghardik } \\
& \text { halusinasinya } \\
& \text { dengan mandiri } \\
& \text { Klien mampu } \\
& \text { mengontrol } \\
& \text { halusinasinya } \\
& \text { dengan cara minum } \\
& \text { obat secara teratur } \\
& \text { 2x/hari dengan } \\
& \text { bantuan perawat } \\
\text { A : Halusinasi Pendengaran }\end{array}$ \\
\hline
\end{tabular}




\begin{tabular}{|c|c|c|c|c|c|}
\hline & 4 & $\begin{array}{l}\text { Diagnosa } \\
\text { Persepsi } \\
\text { Pendenga } \\
\text { Tindakan } \\
\text { Sp2 : M } \\
\text { minum ob } \\
\text { Rencana T } \\
\text { Sp3 : N } \\
\text { bercakap- }\end{array}$ & $\begin{array}{l}\text { Keperawatan : Gangguan } \\
\text { Sensori : Halusinasi } \\
\text { an } \\
\text { Keperawatan : } \\
\text { engontrol halusinasi dengan } \\
\text { t secara teratur } \\
\text { indak Lanjut : } \\
\text { engontrol halusinasi dengan } \\
\text { akap dengan orang lain }\end{array}$ & $\begin{array}{l}(+) \\
P:\end{array}$ & $\begin{array}{l}\text { Mengenal } \\
\text { halusinasinya cara } \\
\text { Latihan secara } \\
\text { menghardik } \\
\text { halusinasi 2x/hari } \\
\text { Minum obat } \\
\text { teratur 2x/hari }\end{array}$ \\
\hline $\begin{array}{l}\text { Jumat } \\
28 / 02 / 22 \\
\text { Jam } 15.00\end{array}$ & 1 & $\begin{aligned} \text { Data: } & \\
& \\
& \\
& \\
& \end{aligned}$ & $\begin{array}{l}\text { Keluarga klien mengatakan } \\
\text { bahwa klien sering bicara- } \\
\text { bicara sendiri di rumah } \\
\text { Klien sering mendengarkan } \\
\text { suara } \quad \text { - suara yang } \\
\text { menyuruhnya untuk pergi } \\
\text { Klien terkadang tampak } \\
\text { senang ketika halusinasi iu } \\
\text { datang } \\
\text { Klien mengatakan suara - } \\
\text { suara tersebut muncul } 2 \text { kali/ } \\
\text { hari, muncul pada saat pagi } \\
\text { setelah bangun tidur dan } \\
\text { malam sebelum tidur . } \\
\text { Klien mengatakan suara itu } \\
\text { muncul ketika menyendiri } \\
\text { dan kurang tidur } \\
\text { Klien mengatakan ketika } \\
\text { suara itu muncul dia merasa } \\
\text { gelisah }\end{array}$ & $\mathrm{O}:$ & $\begin{array}{l}\text { Klien tampak senang } \\
\text { Klien semangat } \\
\text { untuk dibantu } \\
\text { Klien sudah mampu } \\
\text { mengenali } \\
\text { halusinasinya } \\
\text { dengan mandiri } \\
\text { Klien mampu } \\
\text { melakukan cara } \\
\text { menghardik } \\
\text { halusinasinya } \\
\text { dengan mandiri } \\
\text { Klien mampu } \\
\text { mengontrol } \\
\text { halusinasinya } \\
\text { dengan cara minum } \\
\text { obat secara teratur } \\
\text { 2x/hari dengan } \\
\text { bantuan perawat }\end{array}$ \\
\hline
\end{tabular}




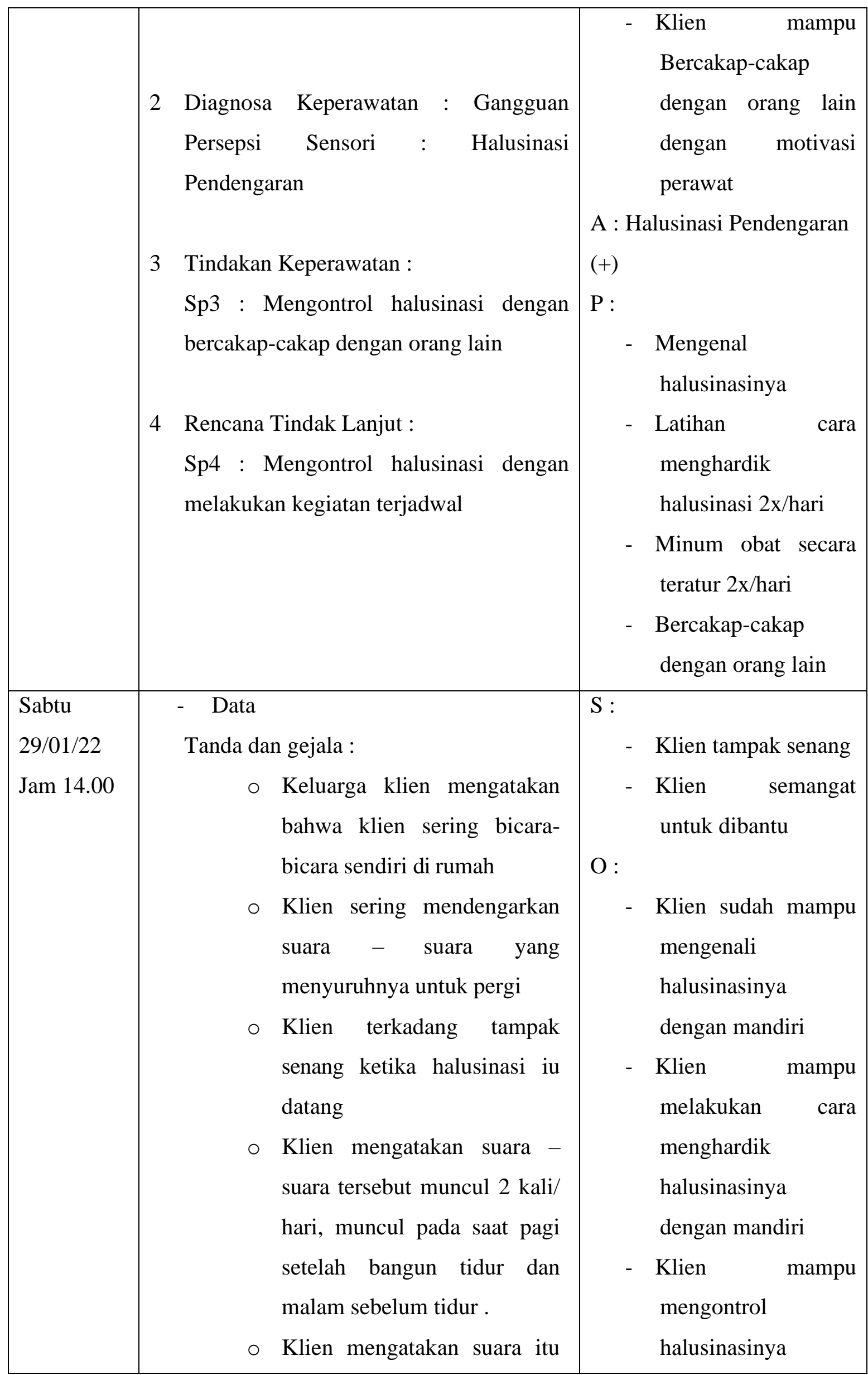




\begin{tabular}{|c|c|c|}
\hline & $\begin{array}{l}\text { muncul ketika menyendiri } \\
\text { dan kurang tidur } \\
\text { O Klien mengatakan ketika } \\
\text { suara itu muncul dia merasa } \\
\text { gelisah } \\
\text { - Diagnosa Keperawatan : } \\
\text { Gangguan Persepsi Sensori : Halusinasi } \\
\text { Pendengaran } \\
\text { - Tindakan Keperawatan } \\
\text { Sp4 : Mengontrol halusinasi dengan } \\
\text { melakukan kegiatan terjadwal } \\
\text { - Rencana Tindak Lanjut: } \\
\text { - Follow up dan evalusi Sp1-Sp4 } \\
\text { Gangguan Persepsi Sensori } \\
\text { Halusinasi Pendengaran } \\
\text { Gangguan Konsep Diri : Harga Diri } \\
\text { Rendah }\end{array}$ & 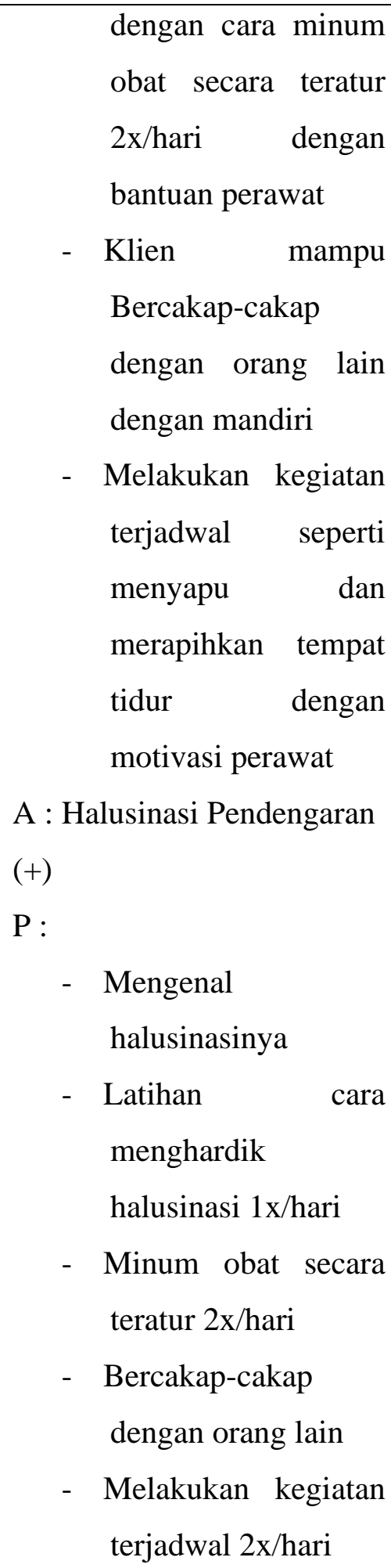 \\
\hline $\begin{array}{l}\text { Senin } \\
31 / 01 / 22 \\
\text { Jam } 11.00\end{array}$ & $\begin{array}{l}\text { 1 Data } \\
\text { - Klien mengatakan merasa malu dan } \\
\text { kurang percaya diri karena kulitnya } \\
\text { penuh bekas luka bakar } \\
\text { - Klien mengatakan hanya } \\
\text { menyusuhkan keluarga dan ingin }\end{array}$ & $\begin{array}{l}\text { S : Senang } \\
\text { O : } \\
\text { - } \\
\text { Klien mampu } \\
\text { mengidentifikasi } \\
\text { kemampuan dan } \\
\text { aspek positif yang }\end{array}$ \\
\hline
\end{tabular}




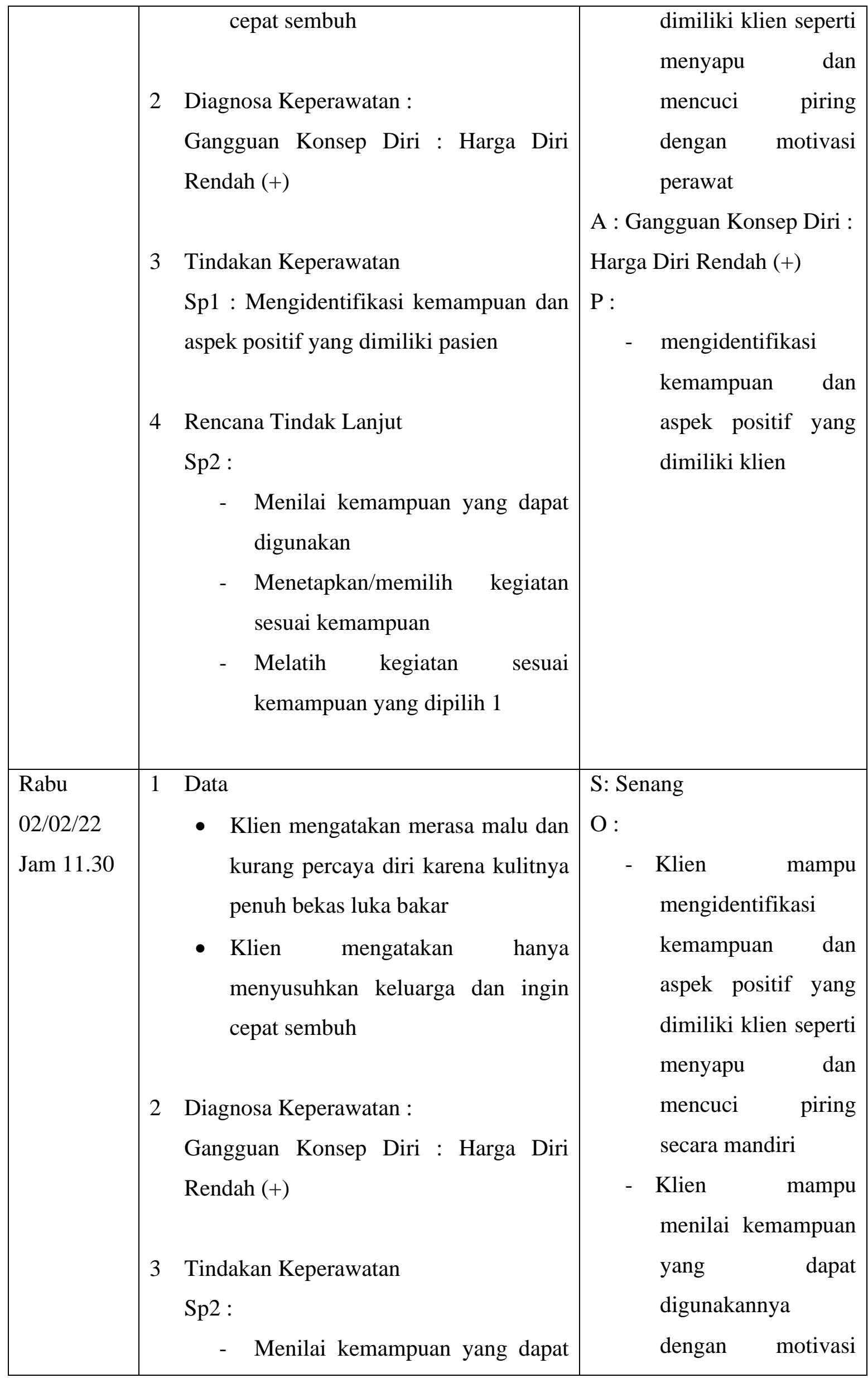




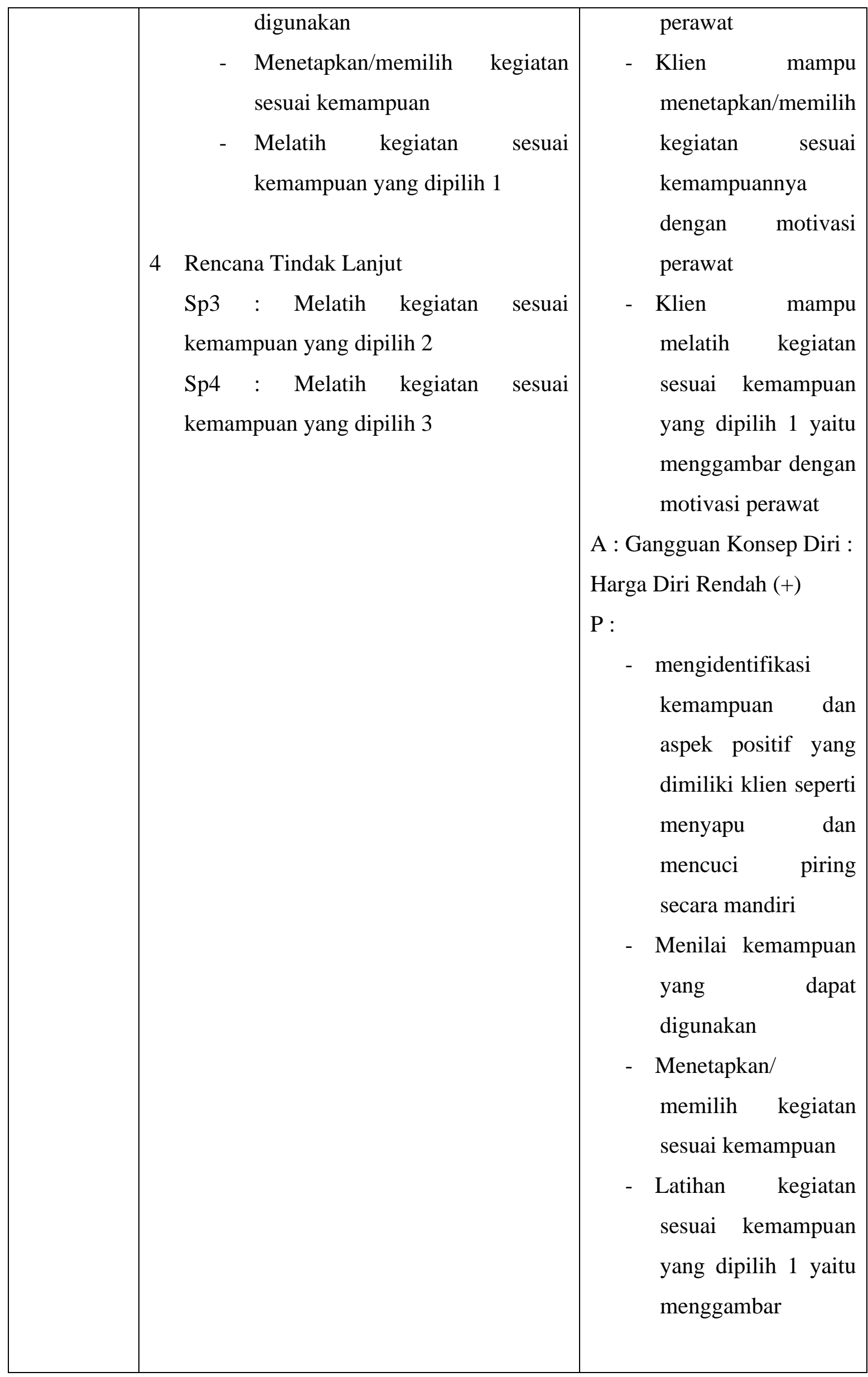




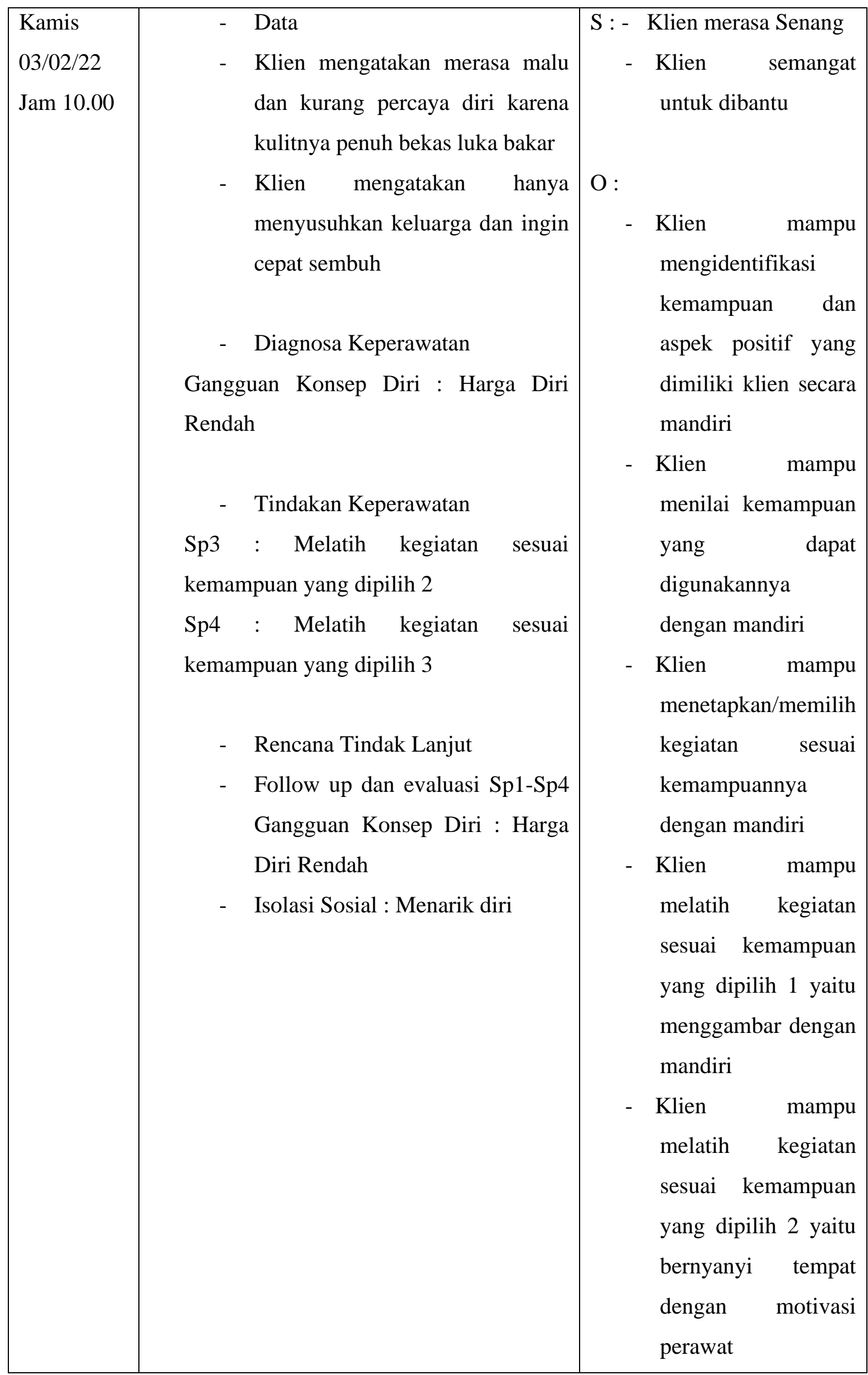




\begin{tabular}{|c|c|c|}
\hline & & $\begin{array}{llr}\text { - } & \text { Klien mampu } \\
& \text { melatih kegiatan } \\
& \text { sesuai kemampuan } \\
& \text { yang dipilih } 3 \text { yaitu } \\
& \text { menyuci piring } \\
& \text { dengan motivasi } \\
& \text { perawat } \\
\text { A : Gangguan Konsep Diri : } & \\
\text { Harga } & \text { Diri Rendah (+) } \\
\text { P : } & \\
\text { - } & \text { mengidentifikasi } \\
& \text { kemampuan dan } \\
& \text { aspek positif yang } \\
& \text { dimiliki klien secara } \\
& \text { mandiri } \\
\text { - } & \text { Menilai kemampuan } \\
& \text { yang } \\
& \text { digunakan } \\
\text { - } & \text { Menetapkan/ } \\
\text { memilih kegiatan } \\
\text { sesuai kemampuan } \\
\text { - Latihan kegiatan } \\
\text { sesuai kemampuan } \\
\text { yang dipilih 1 yaitu } \\
\text { menggambar } \\
\text { - Latihan kegiatan } \\
\text { sesuai kemampuan } \\
\text { yang dipilih } 2 \\
\text { - Latihan kegiatan } \\
\text { sesuai kemampuan } \\
\text { yang dipilih } 3\end{array}$ \\
\hline $\begin{array}{l}\text { Jumat } \\
04 / 02 / 22 \\
\text { Jam } 11.00\end{array}$ & $\begin{array}{l}\text { 1. Data } \\
\text { - Klien mengatakan dirinya lebih } \\
\text { senang untuk menyendiri }\end{array}$ & $\begin{array}{l}\text { S : Senang } \\
\text { O : } \\
\quad \text { - Klien }\end{array}$ \\
\hline
\end{tabular}




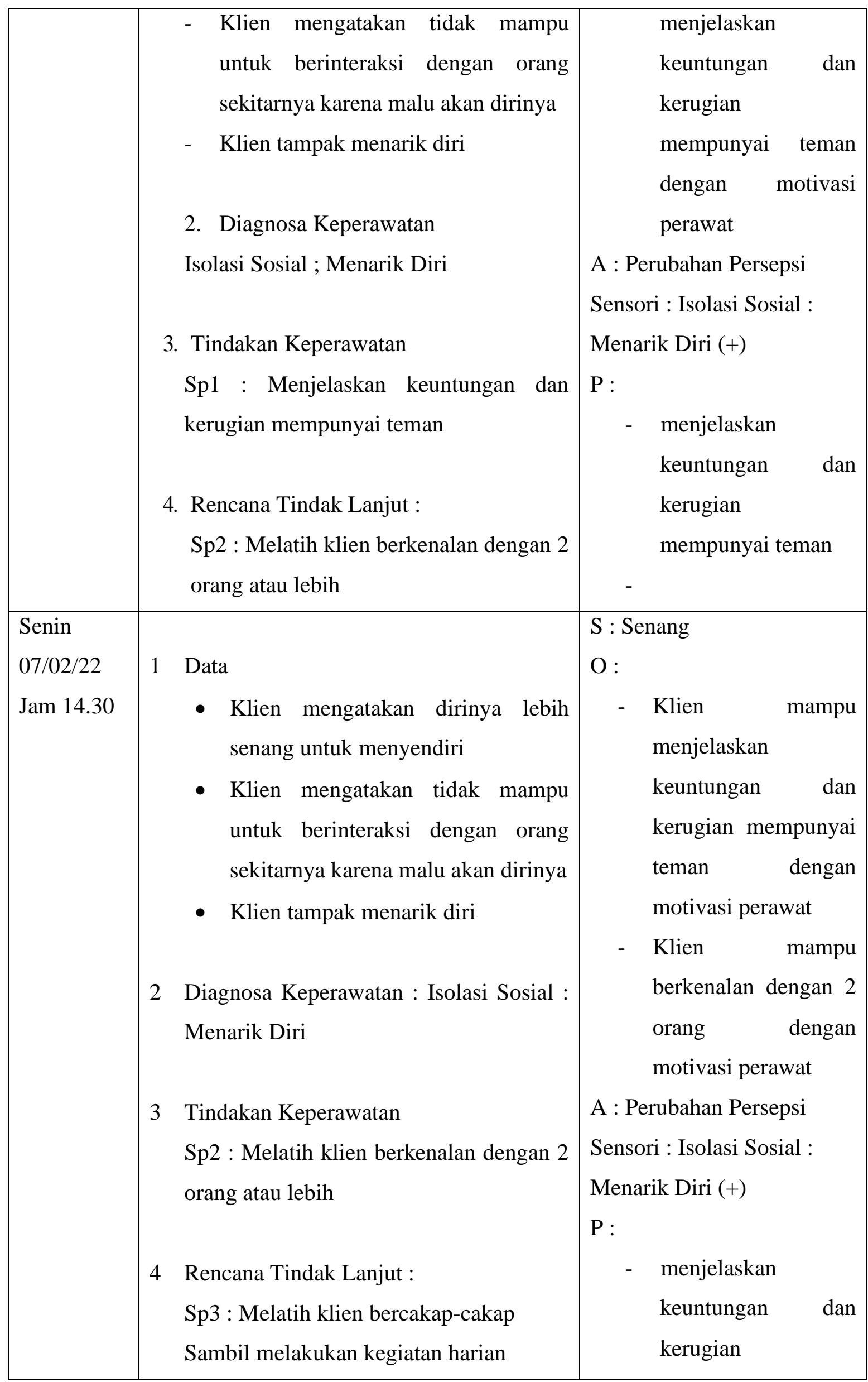




\begin{tabular}{|c|c|c|}
\hline & & $\begin{array}{l}\text { mempunyai teman } \\
\text { Latihan berkenalan } \\
\text { dengan } 2 \text { orang atau } \\
\text { lebih }\end{array}$ \\
\hline $\begin{array}{l}\text { Selasa } \\
\text { 08/02/22 } \\
\text { Jam } 14.30\end{array}$ & 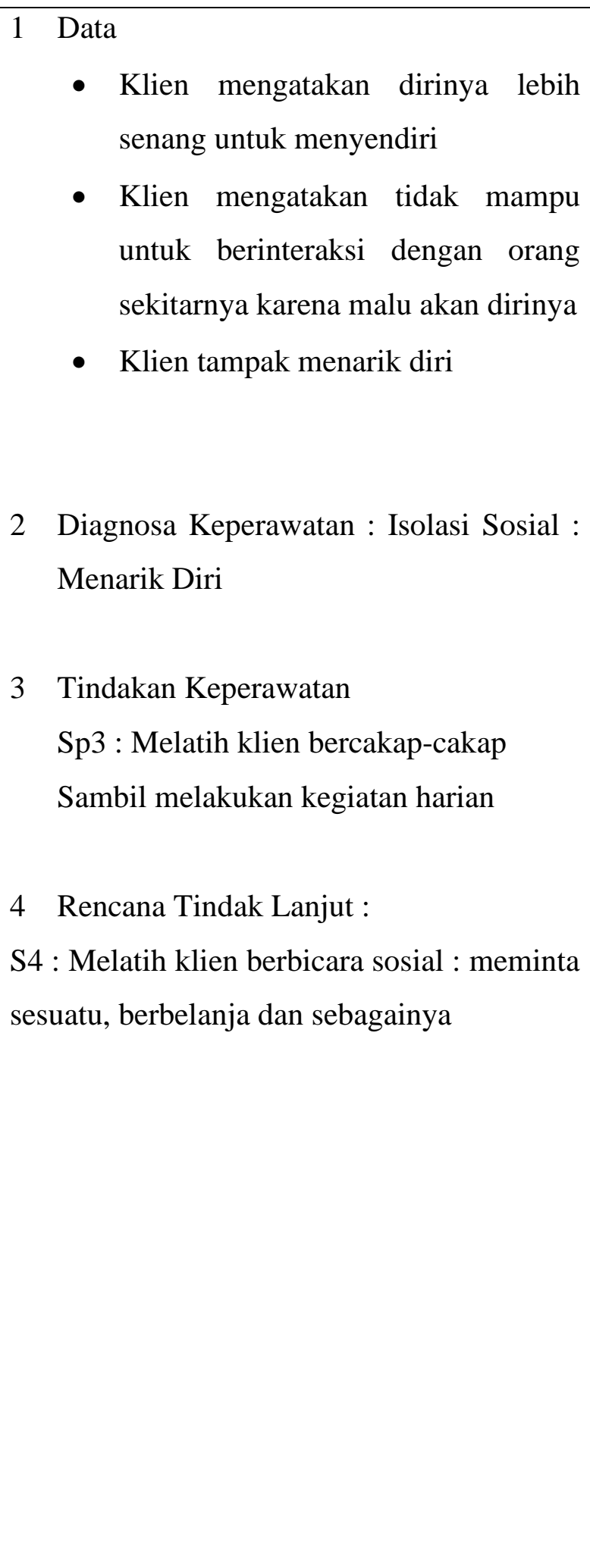 & 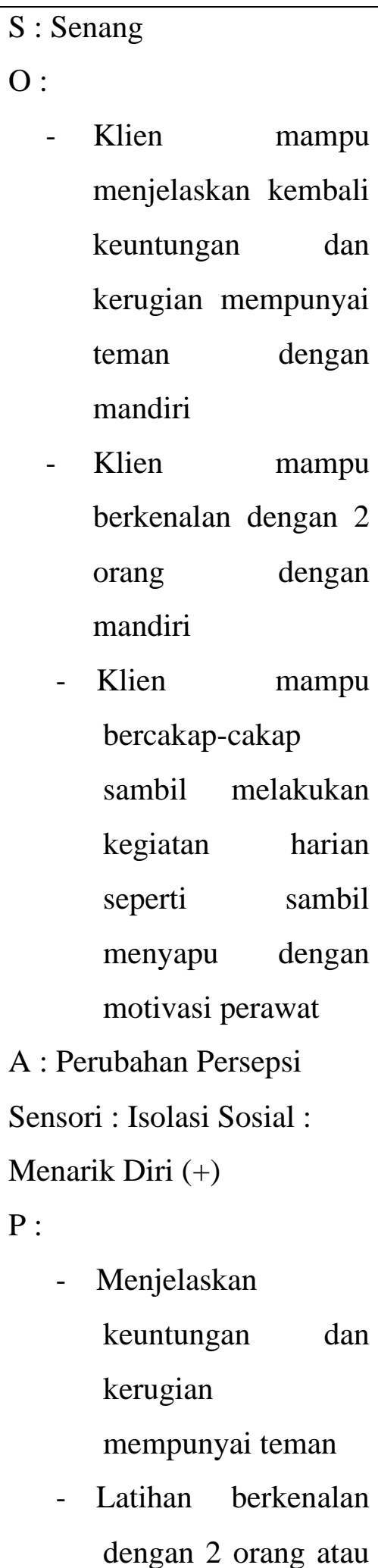 \\
\hline
\end{tabular}




\begin{tabular}{|c|c|c|c|}
\hline & & & 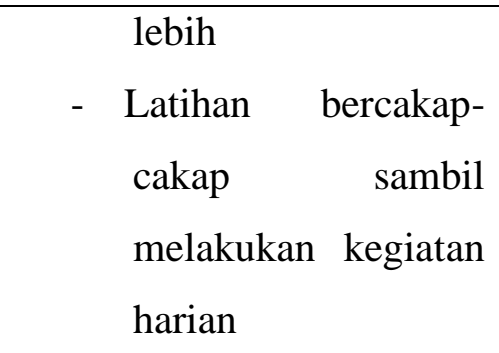 \\
\hline $\begin{array}{l}\text { Rabu } \\
09 / 02 / 22 \\
\text { Jam } 14.30\end{array}$ & 3 & $\begin{array}{l}\text { Data } \\
\text { - Klien mengatakan dirinya lebih } \\
\text { senang untuk menyendiri } \\
\text { - Klien mengatakan tidak mampu } \\
\text { untuk berinteraksi dengan orang } \\
\text { sekitarnya karena malu akan dirinya } \\
\text { - Klien tampak menarik diri } \\
\text { Diagnosa Keperawatan } \\
\text { Isolasi Sosial ; Menarik Diri } \\
\text { Tindakan Keperawatan } \\
\text { Sp4 : Melatih klien berbicara sosial : } \\
\text { meminta sesuatu, berbelanja dan } \\
\text { sebagainya } \\
\text { Rencana Tindak Lanjut } \\
\text { Follow up dan evaluasi Sp1-Sp4 } \\
\text { Isolasi Sosial }\end{array}$ & 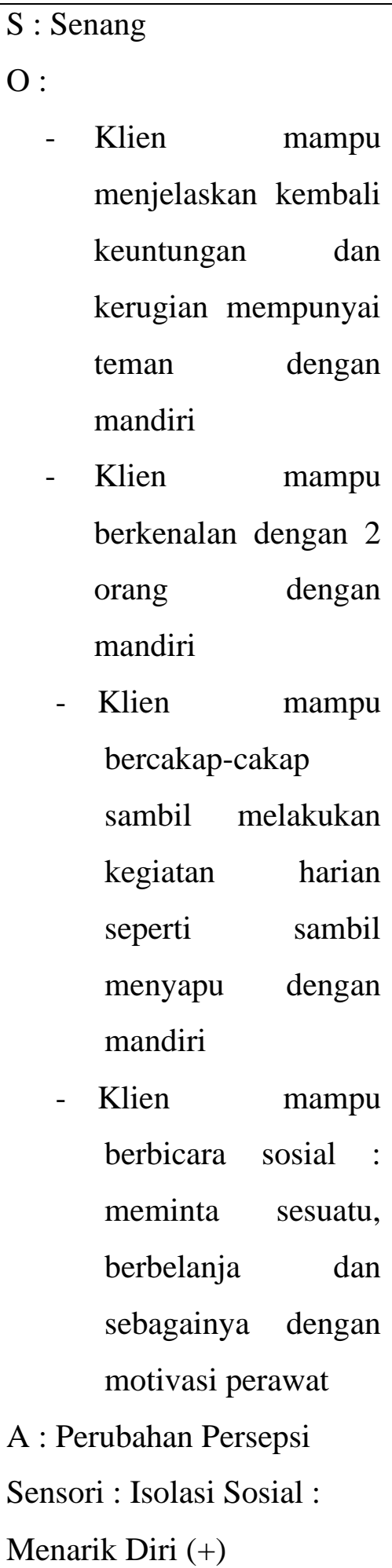 \\
\hline
\end{tabular}




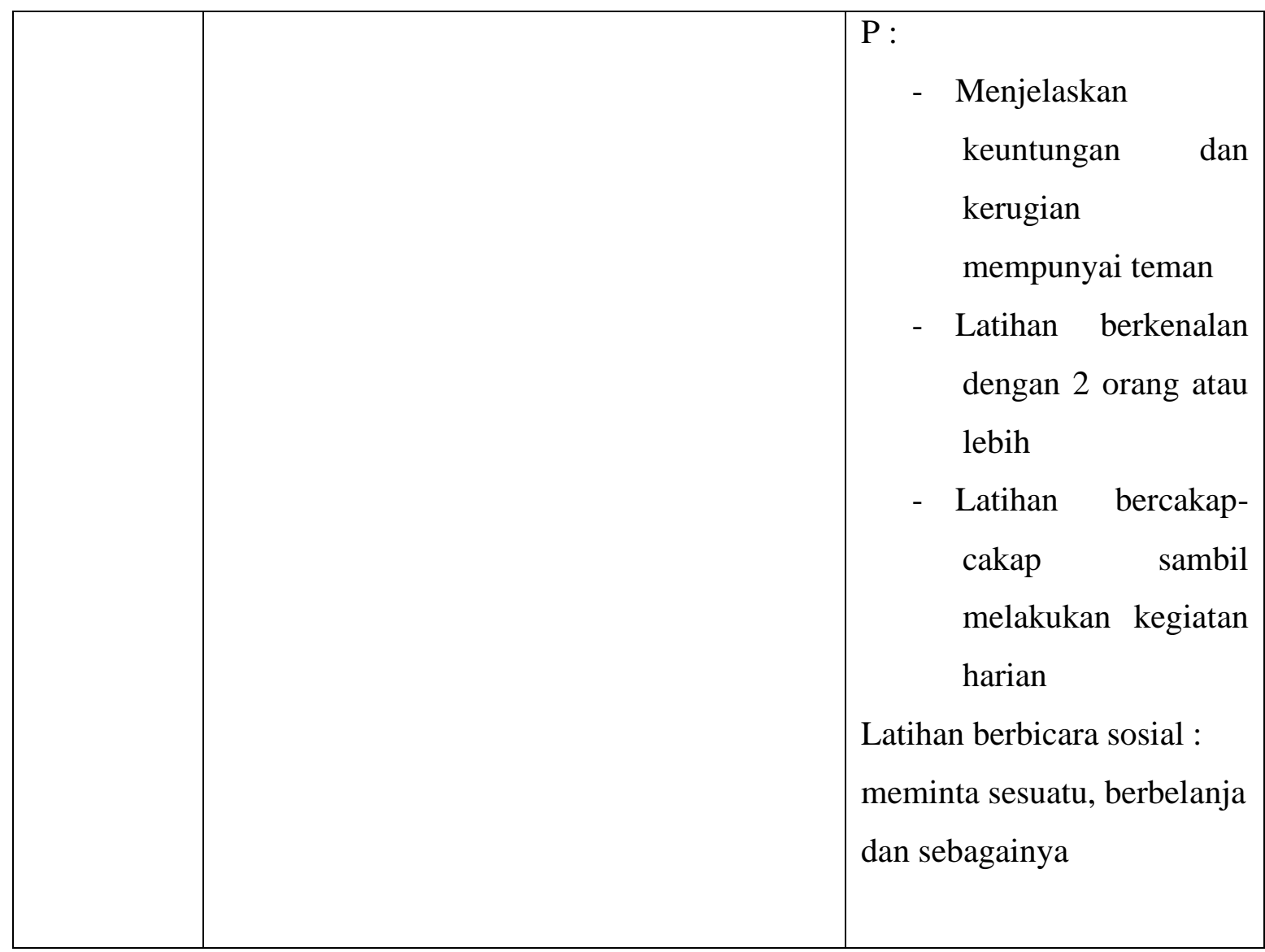




\section{BAB 4 \\ PEMBAHASAN}

Setelah penulis melaksanakan asuhan keperawatan kepada Ny.F dengan gangguan sensori persepsi: halusinasi pendengaran di Ruangan Cempaka Rumah Sakit Jiwa maka penulis pada BAB ini akan membahas kesenjangan antara teoritis dengan tinjauan kasus. Pembahasan dimulai melalui tahapan proses keperawatan yaitu pengkajian, diagnosa keparawatan, perencanaan, pelaksanaan dan evaluasi.

\subsection{Pengkajian}

Dalam hal ini pembahasan diuraikan tentang hasil pelaksanaan tindakan keperawatan dengan pemberian terapi generalis pada klien halusinasi pendengaran. Pembahasan situasi yang terjadi menyangkut analisis hasil penerapan terapi generalis terhadap masalah keperawatan halusinasi pendengaran. Tindakan situasi keperawatan didasarkan pada pengkajian dan diagnosis yang terjadi dalam keperawatan yang terdiri dari tindakan generalis yang dijabarkan sebagai berikut. Tahap pengkajian pada klien halusinasi dilakukan interaksi perawat-klien melalui komunikasi terapeutik untuk mengumpulkan data dan informasi tentang status kesehatan klien. Pada tahap ini terjadi proses interaksi manusia, komunikasi, transaksi dengan peran yang ada pada perawat sebagaimana konsep tentang manusia yang bisa dipengaruhi dengan adanya proses dalam interpersonal (Keliat, 2016)..

Setiap pengkajian dilakukan pengumpulan data dari beberapa sumber, yaitu dari pasien dan tenaga kesehatan di ruangan. Penulis mendapat sedikit kesulitan dalam menyimpulkan data karena keluarga pasien jarang mengunjungi pasien di rumah sakit jiwa. Maka penulis melakukan pendekatan kepada pasien melalui komunikasi terapeutik yang lebih terbuka membantu pasien untuk memecahkan perasaannya dan juga melakukan observasi kepada pasien.

Adapun upaya tersebut yaitu:

- Melakukan pendekatan dalam membina hubungan saling percaya diri pada klien agar klien lebih terbuka dan lebih percaya dengan menggunakan perasaan.

- Mengadakan pengkajian klien dengan wawancara

Dalam pengkajian ini, penulis menemukan kesenjangan karena ditemukan. Pada kasus

Ny.F klien mendengar suara-suara aneh, mondar-mandir, tampak tegang, putus asa, sedih dan lain-

lain. Gejala gejala yang muncul tersebut tidak semua mencakup dengan yang ada di teori 
klinis ari halusnasi (Keliat,2015). Akan tetapi terdapat faktor predisposisi maupun presipitasi yang menyebabkan kekambuhan penyakit yang dialami oleh Ny.F Tindakan keperawatan terapi generalis yang dilakukan pada Ny.F adalah strategi pertemuan pertama sampai pertemuan empat. Strategi pertemuan pertama meliputi mengidentifikasi isi, frekuensi, jenis, dan respon klien terhadap halusinasi serta melatih cara menghardik halusinasi. Strategi pertemuan kedua yang dilakukan pada Ny.F meliputi melatih cara mengendalikan dengan bercakap-cakap kepada orang lain. Strategi pertemuan yang ketiga adalah menyusun jadwal kegiatan bersama- sama dengan klien. Strategi pertemuan keempat adalah mengajarkan dan melatih Ny.F cara minum obat yang teratur.

\subsection{Diagnosa Keperawatan}

Pada Teori Halusinasi (NANDA, 2015-2017), diagnosa keperawatan yang muncul sebanyak 3 diagnosa keperawatan yang terjadi yaitu:

1. Halusinasi

2. Harga diri Rendah

3. Isolasi Sosial

Sedangkan pada kasus Ny.F ditemukan diagnosa keperawatan yang muncul yang meliputi: isolasi sosial, halusinasi. Dari hal tersebut di atas dapat dilihat terjadi kesamaan antara teori dan kasus. Dimana semua diagnosa pada teori muncul pada kasus Ny.F 


\subsection{Intervensi}

Intervensi dilakukan masalah keperawatan gangguan sensori persepsi: halusinasipada penelitian ini menggunakan intervensi strategi pelaksanaan (SP) dan ditambah dengan intervensi inovasi terapipenerimaan dan komitment (acceptance and commitment therapy).Strategi pelaksanaan(SP) pada intervensi masalah keperawatan gangguan sensori persepsi: halusinasi dapat diimplementasikan secara keseluruhan kepada Ny. F selama yang terjadi 4hari, hal ini didukung oleh klien telah kooperatif dalam menerima masukan/ intervensi yang diberikan oleh penulis. Begitu juga intervensi inovasi terapipenerimaan dan komitment (acceptance and commitment therapy) dapat diaplikasikan kepada klien salama 4hari.

Intervensi inovasi yang dilakukan sesuai SOP yang telah dibuat edangkan untuk intervensi keperawatan pada masalah keperawatan harga diri rendah kronik hanyadapat diimplementasikan kepada klienselama 2 harikarena penulis harus terus menerus mengulang tindakan keperawatan intervensi SP gangguan sensori persepsi: halusinasidan intervensi inovasi terapipenerimaan dan komitment (acceptance and commitment therapy) agar klien lebih memahami dan lebih bisa mengaplikasikan intervensi tersebut apabila klien mengalami halusinasi (Avidha,2018).

\subsection{Implementasi}

Pada tahap implementasi yang terjadi, penulis hanya mengatasi 2 masalah keperawatan yakni: diagnosa keperawatan halusinasi pendengaran dan Gangguan harga diri rendah. Pada diagnosa keperawatan gangguan persepsi sensori halusinasi pendengaran dilakukan strategi pertemuan yaitu mengidentifikasi isi, frekuensi, waktu terjadi, perasaan, respon halusinasi. Kemudian strategi pertemuan yang dilakukan yaitu latihan mengontrol halusinasi dengan cara menghardik. Strategi pertemuan yang kedua yaitu anjurkan minum obat secara teratur, strategi pertemuan yang ke tiga yaitu latihan dengan cara bercakapcakap pada saat aktivitas dan latihan strategi pertemuan ke empat yaitu Mengidentifikasi kemampuan aspek positif, mengidentifikasi kemampan pasien,melakukan kegiatan yang terjadwal, melatih pasien berinteraksi dengan orang lain (Andri,2019). 


\subsection{Evaluasi}

Situasi tinajauan teoritis evaluasi yang diharapkan adalah: Pasien mempercayai perawat sebagai terapis, pasien menyadari bahwa yang dialaminya tidak ada objeknya, dapat mengidentifikaasi halusinasi, dapat mengendalikan halusinasi melalui menghardik, latihan bercakap-cakap, melakukan aktivitas serta menggunakan obat secara teratur

Pada tinjauan teoritis evaluasi yang diharapkan adalah:

- Klien mempercayai perawat sebagai terapis

- Klien dapat mengidentifikasi dan mengontrol halusinasi

- Klien dapat mengendalikan halusinasi dengan menghardik

- Klien dapat mengendalikan halusinasi dengan cara minum obat secara teratur

- Klien dapat mengendalikan halusinasi dengan becakap-cakap dengan orang lain

- Klien dapat melakukan halusinasi dengan cara melakukan kegiatan

terjadwal Pada tinjauan kasus evaluasi yang didapatkan adalah:

- Klien sudah dapat mengontrol dan mengidentifikasi halusinasi

- Klien dapat mengendalikan dengan menghardik

- Klien dapat memahami penggunaan obat yang benar

- Klien dapat mengendalikan dengan bercakap-cakap dengan orang lain

- Klien dapat mengendalikan dengan melakukan kegiatan yang sudah di jadwalkan 


\section{BAB 5 \\ PENUTUP}

\subsection{Kesimpulan}

Berdasarkan uraian pada pembahasan di atas, maka penulis dapat disimpulkan bahwa:

1. Pengkajian dilakukan secara langsung pada klien dan juga dengan menjadikan status klien sebagai sumber informasi yang dapat mendukung data-data pengkajian. Selama proses pengkajian, perawat mengunakan komunikasi terapeutik serta membina hubungan saling percaya antara perawat-klien. Pada kasus Ny. F diperoleh bahwa klien mengalami gejala- gejala halusinasi seperti mendengar suara-suara, gelisah, sulit tidur, tampak tegang, mondar-mandir,tidak dapat mempertahankan kontak mata, sedih, malu, putus asa, menarik diri, mudah marah dan lain-lain. Faktor predisposisi pada Ny.F yaitu pernah mengalami gangguan jiwa sebelumnya.

2. Diagnosa keperawatan yang muncul pada kasus Ny.F Halusinasi pendengaran, harga diri rendah. Tetapi pada pelaksanaannya, penulis fokus pada masalah utama yaitu halusinasi pendengaran.

3. Intevensi yang dilakukan kepada Ny. F yaitu sesuai dengan strategi Pelaksanaan: SP 1:

1) Mengidentifikas, isi, frekuensi, wakru terjadi, situasi pencetus, perasaan dan respon halusinasi.

2) Mengontrol halusinasi dengan menghardik

SP 2: Mengontrol halusinasi dengan minum obat secara teratur

SP 3: Mengontrol halusinasi dengan bercakap-cakap dengan orang

lain SP 4: Mengontrol halusinasi dengan melakukan kegiatan terjadwal.

4. implementasi keperawatan disesuaikan dengan strategi pertemuan pada pasien halusinasi pendengaran dan isolasi sosial.

5. Evaluasi pada asuhan keperawatan ini Ny. F mampu melakukan kegiatan yang sudah diajarkan, adanya peningkatan kemampuan klien dalam mengendalikan halusinasi, yang awalnya pasien mengendalikan dengan menutup telinga saja, sekarang mampu mengendalikan dengan cara menghardik.

\subsection{Saran}

1. Bagi Perawat 
Diharapkan dapat menerapkan komunikasi terapeutik dalam pelaksanaan strategi pertemuan 1-4 pada klien dengan halusinasi sehingga dapat mempercepat proses pemulihan klien.

2. Bagi Institusi Pendidikan

Dapat meningkatkan bimbingan praktek lapangan kepada mahasiswa profesi ners sehingga mahasiswa semakin mampu dalam melakukan asuhan keperawatan pada pasien- pasien yang mengalami halusinasi pendengaran.

3. Bagi Pasien

Laporan ini diharapkan dapat menjadi acuan dan referensi dalam memberikan asuhan keperawatan pada klien dengan halusinasi pendengaran 


\section{DAFTAR PUSTAKA}

1. Latifah, L. (2019). Faktor-Faktor Yang Mempengaruhi Perilaku Perawat Dalam Pemberian Obat Pada Pasien Halusinasi. Jurnal'aisyiyah Medika, 4. https://doi.org/10.36729/jam.v4i1.233

2. Muhith, A. (2015). Pendidikan keperawatan jiwa: Teori dan aplikasi. Penerbit Andi

3. Brigitte, A., \& Pavlos, N. J. (2019). Membrane trafficking in osteoclasts and implications for osteoporosis. Biochemical Society Transactions, 47(2), 639-650. 10.1042/BST20180445

4. Ngapiyem, R., \& Kurniawan, E. A. P. B. (2019). Hubungan antara Dukungan Keluarga Dengan Kemampuan Klien Mengontrol Halusinasi Pedengaran Di Poli Jiwa RSJD Dr. RM Soedarjo Provinsi Jawa Tengah Tahun 2018. https://doi.org/10.35913/jk.v6i2.121

5. Nyumirah, S. (2013). Peningkatan kemampuan interaksi sosial (kognitif, afektif dan perilaku) melalui penerapan terapi perilaku kognitif. Jurnal keperawatan jiwa, 1(2). https://doi.org/10.26714/jkj.1.2.2013.\%25p

6. Nyumirah, S. (2014). Manajemen Asuhan Keperawatan Jiwa pada Klien Halusinasi di Ruang Sadewa. Jurnal Keperawatan Jiwa, 2(1), 1-13. https://doi.org/10.26714/jkj.2.1.2014.1-13

7. Pardede, J. A. (2019). Health Education of Drinking Medication Adherence on Schizophrenia Patients. Journal of Psychiatry, 2(2), 723

8. Pardede, J. A. (2013). Pendidikan Kesehatan Kepatuhan Minum Obat Pada Pasien Skizofrenia Di Kecamatan Medan Helvetia. Jurnal Pengmas Mutiara Ners, 1(1)

9. Pardede, J. A., Keliat, B. A., \& Wardani, I. Y. (2013). Pengaruh Acceptance And Commitment Therapy Dan Pendidikan Kesehatan Kepatuhan Minum Obat Terhadap Gejala, Kemampuan Berkomitmen Pada Pengobatan Dan Kepatuhan Pasien Skizofrenia.

10. Afconneri, Y., Lim, K., \& Erwina, I. (2020). Faktor-Faktor Kekambuhan pada Klien Skizofrenia di Poliklinik Rumah Sakit Jiwa Prof. Dr. Hb Sa'anin Padang. Jurnal Endurance: Kajian Ilmiah Problema Kesehatan, 5(2), 321-330. http://doi.org/10.22216/jen.v5i2.3885

11. Andri, J., Febriawati, H., Panzilion, P., Sari, S. N., \& Utama, D. A. (2019). Implementasi keperawatan dengan pengendalian diri klien halusinasi pada pasien skizofrenia. Jurnal Kesmas Asclepius, 1(2), 146-155. https://doi.org/10.31539/jka.v1i2.922

12. Azizah, L., Zainuri, I., \& Akbar, A. (2016). Buku ajar keperawatan kesehatan jiwa. Yogyakarta: Indomedia Pustaka.

13. Damaiyanti dan Iskandar. (2014). Asuhan Keperawatan Jiwa. Bandung : Refika Aditama.

14. Pardede, J. A. (2022). Koping Keluarga Tidak Efektif Dengan Pendekatan Terapi Spesialis Keperawatan Jiwa.

15. Erviana, I., \& Hargiana, G. (2018). Aplikasi Asuhan Keperawatan Generalis Dan Psikoreligius Pada Klien Gangguan Sensori Persepsi: Halusinasi Penglihatan Dan Pendengaran. Jurnal Riset Kesehatan Nasional, 2(2), 114-123. http://dx.doi.org/10.37294/jrkn.v2i2.10

16. Evangelou, A., Ignatiou, A., Antoniou, C., Kalanidou, S., Chatzimatthaiou, S., Shianiou, G., ... \& Pitsouli, C. (2019). Unpredictable effects of the genetic background of transgenic lines in physiological quantitative traits. G3: Genes, Genomes, Genetics, 9(11), 3877- 3890.

17. Evangelou, A., Ignatiou, A., Antoniou, C., Kalanidou, S., Chatzimatthaiou, S., Shianiou, G., ... \& Pitsouli, C. (2019). Unpredictable effects of the genetic background of transgenic lines in physiological quantitative traits. G3: Genes, Genomes, Genetics, 
9(11), 3877- 3890 .

18. Herawati, N., \& Afconneri, Y. (2020). Perawatan Diri Pasien Skizofrenia dengan $\begin{array}{llll}\text { Halusinasi. Jurnal Keperawatan } & \text { Jiwa, }\end{array}$ https://doi.org/10.26714/jkj.8.1.2020.9-20

19. Hidayat, F., Keliat, B. A., \& Mustikasari, M. (2015). Penerapan Cognitif Behavior Therapy pada Klien Halusinasi dan Perilaku Kekerasan dengan Pendekatan Model Stress Adaptasi Stuart dan Model Hubungan Interpersonal Peplau Di Rs Dr Marzoeki Mahdi Bogor. Jurnal Keperawatan Jiwa, 3(1), 28-42. https://doi.org/10.26714/jkj.3.1.2015.28-42

20. Pardede, J.A, Irwan, F., Hulu, E. P., Manalu, L. W., Sitanggang, R., \& Waruwu, J. F. A. P. (2021). Asuhan keperawatan Jiwa Dengan Masalah Halusinasi. https://doi.org/10.31219/osf.io/fdqzn

21. Keliat B, dkk. (2015). Proses Keperawatan Jiwa Edisi II. Jakarta : EGC.

22. Keliat, B.A \& Akemat. (2016). Model Praktik Keperawatan Profesional jiwa. Jakarta: EGC.

23. Kemenkes RI. (2013). Riset Kesehatan Dasar; RISKESDAS. Jakarta: Balitbang Kemenkes RI.

24. Pardede, J. A., Keliat, B. A., \& Yulia, I. (2015). Kepatuhan dan Komitmen Klien Skizofrenia Meningkat Setelah Diberikan Acceptance And Commitment Therapy dan Pendidikan Kesehatan Kepatuhan Minum Obat. Jurnal Keperawatan Indonesia, 18(3), 157- 166. https://doi.org/10.7454/jki.v18i3.419

25. Pratiwi, M., \& Setiawan, H. (2018). Tindakan Menghardik Untuk Mengatasi Halusinasi Pada Klien Skizofrenia Di Rumah Sakit Jiwa. Jurnal Kesehatan, 7(1), 7-13. http://dx.doi.org/10.46815/jkanwvol8.v7i1.76

26. Santri, T. w. (2021, March 18). Asuhan Keperawatan Jiwa Dengan Masalah Gangguan Persepsi Sensori: Halusinasi Pendengaran Pada Ny.S. https://doi.org/10.31219/osf.io/7ckhe

27. Stuart, G. W. (2013). Buku Saku Keperawatan Jiwa . Edisi 5. Jakarta. EGC.

28. Susilawati, S., \& Fredrika, L. (2019). Pengaruh Intervensi Strategi Pelaksanaan Keluarga terhadap Pengetahuan dan Kemampuan Keluarga dalam Merawat Klien Skizofrenia dengan Halusinasi. Jurnal Keperawatan Silampari, 3(1), 405-415. https://doi.org/10.31539/jks.v3i1.898

29. Wahyuni, S., Yuliet, S. N., \& Elita, V. (2012). Hubungan lama hari rawat dengan kemampuan pasien dalam mengontrol halusinasi. Jurnal Ners Indonesia, 1(2), 69-76. https://doi.org/10.26714/jkj.6.2.2018.106-115

30. Pardede, J. A. (2020). Beban Keluarga Berhubungan Dengan Koping Saat Merawat Pasien Halusinasi. Jurnal Ilmu Keperawatan Jiwa, 3(4), 445-452.

31. Manao, B. M., \& Pardede, J. A. (2019). Beban Keluarga Berhubungan Dengan Pencegahan Kekambuhan Pasien Skizofrenia. Jurnal Keperawatan Jiwa, 12(3).

32. Wijayati, F., \& Nurfantri, N. (2019). Penerapan Intervensi Manajemen Halusinasi terhadap Tingkat Agitasi pada Pasien Skizofrenia. Health Information: Jurnal Penelitian, 11(1), 13- 19. https://doi.org/10.36990/hijp.v11i1.86

33. Pardede, J. A. (2020). Decreasing Hallucination Response Through Perception Stimulation Group Activity Therapy In Schizophrenia Patients. Iar Journal of Medical Sciences, 1(6), 304-309.

34. Pardede, J. A. (2020). Family Burden Related to Coping when Treating Hallucination Patients. Jurnal Ilmu Keperawatan Jiwa, 3(4), 453-460. https://doi.org/10.32584/jikj.v3i4.671

35. Yosep I. ( 2011). Keperawatan Jiwa (Edisi Revisi). Bandung: Refika Aditama

36. Yusuf, A., Fitryasari PK, R., \& Nihayati, H. E. (2015). Buku ajar keperawatan kesehatan jiwa.

37. Pardede, J. A., \& Laia, B. (2020). Decreasing Symptoms of Risk of Violent Behavior 
in Schizophrenia Patients Through Group Activity Therapy. Jurnal Ilmu Keperawatan Jiwa, 3(3), 291-300.

38. Zelika, A. A., \& Dermawan, D. (2015). Kajian Asuhan Keperawatan Jiwa Halusinasi Pendengaran Nakula RSJD Surakarta. Profesi (Profesional Islam): Media Publikasi Penelitian, 12(02). http://dx.doi.org/10.26576/profesi.87

39. Zuraida, Z. (2018). Konsep Diri Penderita Skizofrenia Setelah Rehabilitasi. Jurnal Psikologi Kognisi, 1(2), 110-124. http://dx.doi.org/10.22303/kognisi.1.2.2017.110-124 